\title{
Synoptic-Scale Control over Modern Rainfall and Flood Patterns in the Levant Drylands with Implications for Past Climates ${ }^{\mathcal{O}}$
}

\author{
MOSHE ARMON \\ Fredy and Nadine Herrmann Institute of Earth Sciences, Hebrew University of Jerusalem, Givat Ram, Jerusalem, Israel \\ ELAD DENTE \\ Fredy and Nadine Herrmann Institute of Earth Sciences, Hebrew University of Jerusalem, Givat Ram, and Geological \\ Survey of Israel, Jerusalem, Israel \\ JAMES A. SMITH \\ Department of Civil and Environmental Engineering, Princeton University, Princeton, New Jersey \\ YEHOUDA ENZEL AND EFRAT MORIN \\ Fredy and Nadine Herrmann Institute of Earth Sciences, Hebrew University of Jerusalem, Givat Ram, Jerusalem, Israel
}

(Manuscript received 23 January 2018, in final form 1 May 2018)

\begin{abstract}
Rainfall in the Levant drylands is scarce but can potentially generate high-magnitude flash floods. Rainstorms are caused by distinct synoptic-scale circulation patterns: Mediterranean cyclone (MC), active Red Sea trough (ARST), and subtropical jet stream (STJ) disturbances, also termed tropical plumes (TPs). The unique spatiotemporal characteristics of rainstorms and floods for each circulation pattern were identified. Meteorological reanalyses, quantitative precipitation estimates from weather radars, hydrological data, and indicators of geomorphic changes from remote sensing imagery were used to characterize the chain of hydrometeorological processes leading to distinct flood patterns in the region. Significant differences in the hydrometeorology of these three flood-producing synoptic systems were identified: MC storms draw moisture from the Mediterranean and generate moderate rainfall in the northern part of the region. ARST and TP storms transfer large amounts of moisture from the south, which is converted to rainfall in the hyperarid southernmost parts of the Levant. ARST rainfall is local and intense, whereas TP rainfall is widespread and prolonged due to high precipitation efficiency and large-scale forcing. Thus, TP rainfall generates high-magnitude floods in the largest catchments; integration of numerous basins leads to sediment feeding from the south into the Dead Sea, exhibited in large sediment plumes. Anecdotal observations of the channel with the largest catchment in the region (Nahal HaArava) indicate that TP floods account for noticeable geomorphic changes in the channel. It provides insights into past intervals of increased flash flood frequency characterized by episodes of marked hydrogeomorphic work; such an increase is especially expected during intervals of southerly situated and southwesterly oriented STJs.
\end{abstract}

\section{Introduction}

The drylands of the Levant are characterized by meager rainfall amounts (Fig. 1), concentrated in a few convective, spatially spotty, high-intensity and short-duration rainstorms a year (Goldreich 1994; Sharon and Kutiel 1986). In these drylands, rainstorms are caused by diverse synoptic-

Supplemental information related to this paper is available at the Journals Online website: https://doi.org/10.1175/JHM-D-18-0013.s1.

Corresponding author: Moshe Armon, moshe.armon@mail.huji.ac.il. scale patterns, such as the Mediterranean cyclone (MC), the active Red Sea trough (ARST), and subtropical jet stream (STJ)-related disturbances (Dayan and Morin 2006; Kahana et al. 2002). In extreme cases, depending on their rainfall distribution in space and time, associated rainstorms may produce high-magnitude flash floods (Morin and Yakir 2014; Doswell et al. 1996; Lange and Leibundgut 2003; Schick 1988). As in many other dryland settings, flash floods are the most effective hydrogeomorphic agents for channel incision, sediment transport, alluvial aquifer recharge, and filling lowlands with sediment and water (e.g., Grodek et al. 2012; Bull 1988; Enzel et al. 2012). 
(a)

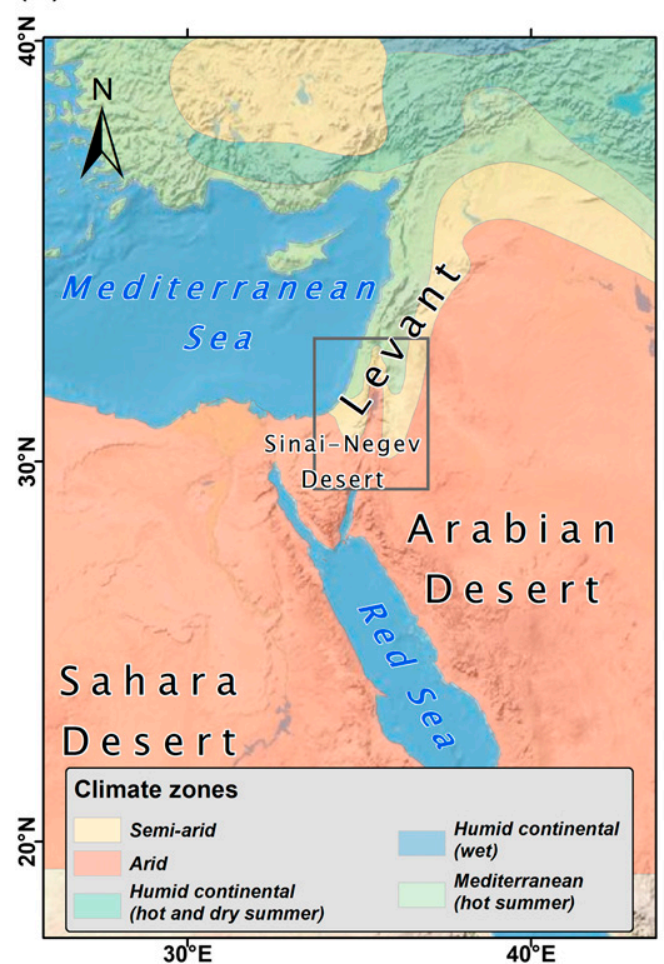

(b)

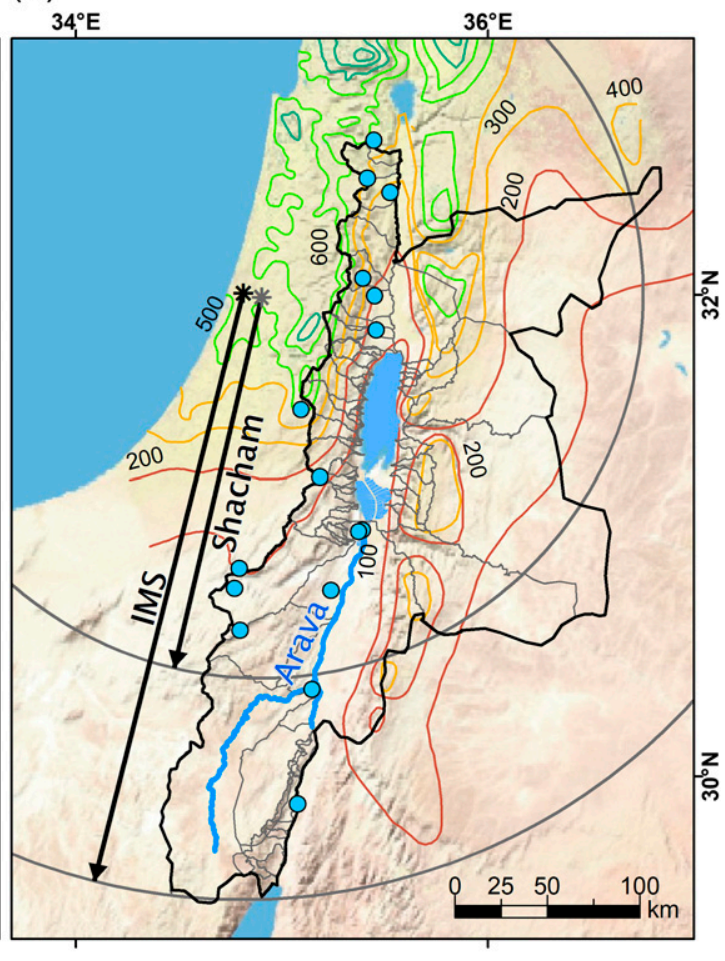

FIG. 1. (a) Location map. The gray rectangle indicates the study region-the Levant drylands. (b) Isohyets (colored and labeled) and the studied catchments (light gray) circumscribed in the black polygon. The channel of the largest watershed, Nahal HaArava, is in blue. Arrows represent the ranges of the two weather radars used in this study. Blue dots represent rain gauges compared to weather radars, to estimate radar rainfall errors (Table 1).

Extreme floods result from unique meteorological conditions, including high atmospheric moisture content, rainfall rates, and precipitation efficiency (Doswell et al. 1996). This combination is achieved through either distinct synoptic-scale circulation patterns or through slow-moving or a train of intense convective rain cells and their possible interaction with the terrain (Panziera et al. 2015; O'Connor and Costa 2004; Bárdossy and Filiz 2005; Tarolli et al. 2012; Smith et al. 2011b; Hirschboeck et al. 2000). It is important to assess such events through accurate spatial rainfall data (e.g., Krajewski and Smith 2002; Fekete et al. 2004). Although rainfall-pattern analysis in scarcely gauged drylands requires remote sensing data, such as weather radars, there is usually a lack of data availability or quality (Tarolli et al. 2012; Morin et al. 2009; Kalma and Franks 2003).

The rarity of extreme events makes it difficult to deduce general conclusions based on a large number of events. Notwithstanding, analysis of a few carefully selected, well-documented, extreme events representing the range of flood-producing synoptic systems can provide insights and enable drawing some more general inferences on the unique characteristics of these systems.

In this study, we present a detailed analysis of a set of case studies to first ask whether these distinct synoptic patterns result in different patterns of rainfall, and, if so, can the specific meteorological mechanism be identified? In turn, can rainfall patterns enforce a change in flash flood patterns (in terms of activated catchment size, magnitude, etc.)? By answering this chain of questions, we will evaluate which of the aforementioned synoptic patterns has the potential to generate the largest floods in terms of water peak discharge and volume. As a result, with the assumption that sediment discharge is related to water discharge, we will examine which pattern has the highest potential to serve as an effective hydrogeomorphic agent and for which size of catchment.

Our efforts are also directed at applying the synoptic pattern's control over precipitation and flooding as a guide for interpreting flood sediments, such as those recovered from the Dead Sea (e.g., Neugebauer et al. 2014; Torfstein et al. 2015; Ahlborn et al. 2018), located 
at the center of the region, and from past fluvial changes in the region's numerous streams (e.g., Matmon et al. 2016; Davis et al. 2009). In this regard, we are searching for the synoptic-scale patterns that can contribute to these floods or scenarios.

More specifically, based on an analysis of six large floods of three synoptic systems, here we 1) characterize the large-scale meteorological conditions leading to major rainstorms and flash floods in the Levant drylands, 2) identify spatiotemporal patterns of rainfall, and 3) present hydrological characteristics of large floods in the southern Levant. This analysis also covers the hydrogeomorphic work revealed through remote sensing tools of the six examined floods, as well as an additional nine significant floods.

In terms of modern hydroclimatology, this study has implications for meteorological impacts on floodwater volume and geomorphic and sedimentological responses in the diverse watersheds of the southern Levant deserts. It may also assist in resolving such questions in other parts of the world where diverse synoptic-scale patterns affect flooding.

The next section describes the general flood hydroclimatology of the southern Levant. The study area, case studies, data, and methodology are then introduced (section 3), followed by results, starting from the largescale meteorological processes through rainfall and flash floods and ending with a subset of geomorphic outcomes of those flash floods (section 4). The discussion (section 5) is supplemented by wider implications for the paleohydrology perspective.

\section{Regional hydroclimatology}

The Levant drylands are situated north of the Sahara and Arabia (Fig. 1a). The main topographic features in the area are the Judean-Negev mountains with peaks of $\sim 1000 \mathrm{~m}$ above sea level, the Dead Sea rift valley (430 m below sea level at its lowest point), and the Jordanian mountain ranges $(\sim 1500 \mathrm{~m})$. Hard carbonate rocks and sandstones, covered in places by a colluvial or thin soil mantle, characterize the region. Vegetation is confined mainly to the stream channels and to the higher altitudes. Autumn to spring rainfall is scarce, and summers are totally dry. Mean annual precipitation, focused in the wintertime, decreases toward the hyperarid regions of Sinai, the Negev, and southern Jordan (Fig. 1b; e.g., Enzel et al. 2015; Goldreich 2012; Kushnir et al. 2017). Although scant, this rainfall produces major flash floods [defined by Kahana et al. (2002) as $>5$-yr return period or $<20 \%$ of annual exceedance probability] in $\sim 70 \%$ of the years. On average, there are almost two such floods per year somewhere in the Negev alone (Kahana et al. 2002).
Three types of synoptic systems comprise the rainfallbearing systems in the region (Kahana et al. 2002; Dayan and Morin 2006):

1) Mediterranean cyclones (also termed Syrian/Cyprus lows, depending on the respective location of their centers) are extratropical cyclones, forming primarily over the high-temperature waters of the Mediterranean Sea, and are influenced by midtropospheric baroclinicity (e.g., Ziv et al. 2015; Kushnir et al. 2017). MCs occur mainly in winter and early spring (December-March) and may produce rainstorms that typically last $2-3$ days (Alpert et al. 2004). According to Kahana et al. (2002), they cause $33 \%$ of the major floods in the Negev.

2) Active Red Sea troughs are associated with heavyprecipitation storms accompanied by a low pressure system centered in Sudan/Arabian Peninsula (Ashbel 1938; Krichak et al. 1997). They only prevail on $<5 \%$ of the days, but they account for $38 \%$ of the major Negev floods (Tsvieli and Zangvil 2005; Kahana et al. 2002). The ARST differs from the nonactive (i.e., dry) Red Sea trough mostly in its upper-level "support" (upper-level, extratropical trough) and in the moisture supply necessary for precipitation. These features enable ARSTs to produce heavy rainfall for short time intervals (de Vries et al. 2013).

3) Subtropical jet-related storms are also known as tropical plumes (TPs), tropical moisture exports (TMEs), or atmospheric rivers (ARs), depending on the studied area and the specific characteristics of the storm (McGuirk et al. 1987; Rubin et al. 2007; Knippertz and Wernli 2010; Tubi and Dayan 2014). These account for $\sim 8 \%$ of the large floods in the Negev and usually produce relatively widespread, prolonged rainfall (Dayan and Abramski 1983; Kahana et al. 2002). This synoptic-scale system is rare and was therefore not captured in earlier analyses. Approximately four TP events occur on average each year in the region of northwestern Arabia, an area that is probably more prone to rainstorms generated by this system; however, only $<30 \%$ of them precipitate (Tubi and Dayan 2014). Thus, there are only a few welldocumented (by weather radars and gauging stations) major flood-producing TPs in the Levant.

Previous studies have used the following terms interchangeably, but not always properly and consistently: STJ, TP, TME, Sudanese tracks, and even AR and moisture conveyor belt (MCB). Here we will term events with a long $(>1000 \mathrm{~km})$ region of elevated mid-to-upperlevel water vapor and with water-vapor transport from North Africa as STJs or TPs, the dominant terminology used for the Levant (e.g., Begin et al. 2004; Enzel et al. 2015; Torfstein et al. 2015; Tubi and Dayan 2014; 
TABLE 1. Properties of the six case studies used for the analysis. Radar RMSE was calculated vs rain gauges throughout the study region (Fig. 1).

\begin{tabular}{|c|c|c|c|c|c|c|}
\hline Start date & End date & Synoptic type & Significant flash floods & Previous studies & Radar system used & $\operatorname{RMSE}(\mathrm{mm})$ \\
\hline 10 Dec 2013 & 14 Dec 2013 & $\mathrm{MC}$ & $\begin{array}{l}\text { Arugot stream } \\
\qquad\left(235 \mathrm{~km}^{2} ; 107 \mathrm{~m}^{3} \mathrm{~s}^{-1}\right)\end{array}$ & Luo et al. (2015) & IMS & 14.7 \\
\hline 18 Feb 2015 & 23 Feb 2015 & MC & $\begin{array}{l}\text { Heimar stream } \\
\quad\left(359 \mathrm{~km}^{2} ; 156 \mathrm{~m}^{3} \mathrm{~s}^{-1}\right)\end{array}$ & & IMS & 17.3 \\
\hline 02 Nov 1994 & 06 Nov 1994 & ARST & $\begin{array}{l}\text { Paran stream } \\
\qquad\left(3372 \mathrm{~km}^{2} ; 370 \mathrm{~m}^{3} \mathrm{~s}^{-1}\right)\end{array}$ & $\begin{array}{l}\text { Krichak et al. (2000); } \\
\text { de Vries et al. (2013) }\end{array}$ & Shacham & 12.3 \\
\hline 21 Dec 1993 & 23 Dec 1993 & ARST & $\begin{array}{l}\text { Neqarot stream } \\
\quad\left(710 \mathrm{~km}^{2} ; 708 \mathrm{~m}^{3} \mathrm{~s}^{-1}\right)\end{array}$ & $\begin{array}{l}\text { Ziv et al. (2005); } \\
\text { de Vries et al. (2013) }\end{array}$ & Shacham & 9.7 \\
\hline 07 May 2014 & 13 May 2014 & ТP & $\begin{array}{l}\text { Darga stream } \\
\qquad\left(75 \mathrm{~km}^{2} ; 250 \mathrm{~m}^{3} \mathrm{~s}^{-1}\right)\end{array}$ & $\begin{array}{l}\text { Farhan and Anbar (2014); } \\
\quad \text { Ginat and Shalmon (2014) }\end{array}$ & IMS & 13.3 \\
\hline 17 Jan 2010 & 20 Jan 2010 & TP & $\begin{array}{l}\text { Paran stream } \\
\quad\left(3372 \mathrm{~km}^{2} ; 880 \mathrm{~m}^{3} \mathrm{~s}^{-1}\right)\end{array}$ & & IMS & 10.2 \\
\hline
\end{tabular}

Waldmann et al. 2010). Recent discussions of these terms are found in Ralph et al. (2017), Dacre et al. (2015), and Knippertz and Martin (2007), and references therein.

\section{Methods and data}

The study region (Fig. 1b) is composed of catchments 1) with a relatively large fraction of dryland area (hyperarid, arid, and semiarid regions; Fig. 1), 2) located within the coverage of a weather radar (Fig. 1b), and 3) located far enough from the Mediterranean Sea that they are not influenced solely by MCs (according to Kahana et al. 2002; Goldreich et al. 2004).

Six recent major flood-producing storms in the Levant were examined and used to characterize and identify major ingredients (after Doswell et al. 1996) contributing to flood characteristics and resulting in hydrological and geomorphic changes (Table 1; see also Fig. S1 with the regional envelope curve in the online supplemental material). Two storms for each of the major synoptic systems (MC, ARST, and TP/STJ) were selected. We specifically chose extreme events 1) consisting of a clear and straightforward synoptic classification, 2) presenting a sufficient amount and quality of radar rainfall and flood-discharge data, and 3) producing numerous floods in the southern, most arid parts of the region. This type of event is, by definition, quite rare, even with the relatively long available record, since MCs usually do not generate rainfall in the southern part of the study area (e.g., Amit et al. 2006; Enzel et al. 2008; Kushnir et al. 2017; Kahana et al. 2002). ARSTs generate mainly isolated rainfall showers and only a few flash floods in one event (Kahana et al. 2002; Kushnir et al. 2017), and, as already noted, major TP events are not frequent.

\section{a. Meteorological and hydrological data}

Meteorological conditions over the eastern Mediterranean and its surrounding deserts during the selected events were characterized using data obtained from the European Centre for Medium-Range Weather Forecasts (ECMWF) interim reanalysis (ERA-Interim; Dee et al. 2011); the NERC Satellite Receiving Station, Dundee University, Scotland (satellite imaging; www.sat.dundee. ac.uk/); the International Satellite Cloud Climatology Project (ISCCP; https://www.ncdc.noaa.gov/gibbs/; Knapp 2008), and the University of Wyoming (upper-air soundings; http://weather.uwyo.edu/upperair/sounding.html). Air parcels' back trajectories were computed using the National Oceanic and Atmospheric Administration (NOAA) Air Resources Laboratory's Hybrid Single-Particle Lagrangian Integrated Trajectory model (HYSPLIT; Stein et al. 2015).

Moisture sources were identified using analysis of atmospheric moisture content [total column water (TCW): the total amount of water vapor integrated along a $1 \mathrm{~m}^{2}$ column of air] and flux, air parcel trajectories, and the change in specific moisture along the trajectory.

Rainfall patterns were identified through quantitative precipitation estimation (QPE) from two C-band weather radars (Fig. 1b): the Israeli Meteorological Service (IMS) radar located at Bet Dagan $\left(32.00^{\circ} \mathrm{N}, 34.81^{\circ} \mathrm{E}\right)$ and the nearby Electrical Mechanical Services (EMS/ Shacham) radar, located at Ben Gurion Airport $\left(31.99^{\circ} \mathrm{N}\right.$, $\left.34.90^{\circ} \mathrm{E}\right)$. Shacham radar data are based on Marra and Morin (2015) and were used for case studies before 2010. Later rainstorms were analyzed using the IMS radar data. Rain intensities for both datasets were computed from radar reflectivity using a power-law relationship followed by gauge-adjustment procedures after Morin and Gabella (2007). The root-mean-square error (RMSE) of total storm rain depth of radar QPE versus rain gauges covered by the radar and located throughout the study region (Fig. 1b) is shown in Table 1.

Flash flood discharge data were obtained from hydrometric stations of the Israeli Hydrological Service 
and from documented postflood surveys. The number of different measurements was 12-44 for the selected events. These data represent catchments that vary in size from 4 to $8250 \mathrm{~km}^{2}$. Maximal specific peak discharge (instantaneous peak discharge divided by watershed area) was calculated for each location, and flood volume was extracted for locations where hydrographs were available from hydrometric stations.

\section{b. Geomorphic analysis through remote sensing: Nahal HaArava}

Studying the geomorphic implications of flash floods over all catchments in the study region is probably an impossible task, well beyond the scope of this study. We focused here on the Nahal HaArava channel, the largest $\left(\sim 13 \times 10^{3} \mathrm{~km}^{2}\right)$ watershed in the region and the largest feeder of sediment and water to the Dead Sea lake from the south (Fig. 1b; e.g., Greenbaum et al. 2006a). The Nahal HaArava watershed extends from the Sinai Peninsula (Egypt), through the Negev (Israel), and the Edom Mountains (Jordan), and flows into the Dead Sea (Fig. 1b). The channel reacts to the Dead Sea level drop by incision, narrowing, and meandering (Dente et al. 2017). In this watershed, we identified geomorphic changes by a large number of floods (Table S1). Hypopycnal sediment plumes can be observed during and after seasonal floods in this channel (e.g., Nehorai et al. 2013). These sediment plumes indicate the relative hydrogeomorphic impact and sediment delivery of a flood. At the outlet of a stream of this size, the plumes can represent the cumulative effect of flash floods coevally affecting several subbasins in the watershed.

Analysis of the geomorphic effects of flash floods was based on remote sensing, including Moderate-Resolution Imaging Spectroradiometer (MODIS), Landsat imagery, and aerial photographs. The satellite products' resolution ranged from at least one image per day and $1 \mathrm{~km}$ (MODIS) to one image every 2-4 weeks and $30 \mathrm{~m}$ (Landsat). The relatively frequent MODIS and Landsat imagery captures flash flood effects during and shortly after the event. However, their low spatial resolution is only suitable for identifying large-scale geomorphic changes along the channel. These include sediment plumes (MODIS) and width changes, delta evolution, and major channel shifts (Landsat). Aerial photographs (from the Geological Survey of Israel's archive) have high spatial resolution (from $12.5 \mathrm{~cm}$ to a few meters per pixel), and thus, they are suitable for the detection of subtler geomorphic changes along the channel. On the other hand, their temporal resolution is characterized by intervals of $\sim 1-2$ years (starting in the early 1990s). This relatively low temporal resolution makes it difficult to isolate the effect of a specific flash flood. The data used for the analysis were for the six aforementioned case studies
(Table 1) and nine additional significant rainstorms between 1985 and 2015 (Table S1). For these nine storms, we followed the same practice as before, except that unfortunately, they were not covered by other types of data, and thus they were unsuitable for the other parts of this study.

\section{Results}

\section{a. Moisture sources and dynamics}

The moisture sources contributing to rainstorms are key factors in characterizing those storms (Krichak and Alpert 1998; Gimeno et al. 2012). Here we identified these sources using back trajectories (e.g., Tubi and Dayan 2014); this was elaborated by analyzing the specific humidity and vertically integrated moisture-flux patterns, such that a major increase in humidity followed by a major moisture flux was interpreted as a moisture source (Fig. 2; Figs. S2-S7 and Supplementary Videos S1-S6). TP, ARST, and MC rainstorms differ drastically in their moisture origins and dynamics. Moisture in the examined $\mathrm{MC}$ rainstorms originates primarily from the eastern Mediterranean Sea (Figs. 2, S2, S3 and Videos S1, S2), as, for example, in Alpert and Shay-El (1994) and Zangvil and Druian (1990). Moisture for ARST rainstorms originates in the Red and Arabian Seas (Figs. 2, S4, S5 and Videos S3, S4), similar to the results of de Vries et al. (2013). This moisture travels above the Red Sea, funneled by its peripheral mountain ranges, mostly in the mid- and lower-tropospheric levels, to the Levant. The moisture for the TP rainstorms is considered of equatorial origin, far to the southwest of the study area, and it is transported through the STJ, as previously shown by Rubin et al. (2007). Tracking the change in moisture content throughout the TP's course (Figs. 2, S6, S7 and Videos S5, S6) revealed two additional possible moisture sources and mechanisms. The first is by dry air rising above the Sahara to the upper part of the troposphere. Thermodynamic instability, caused by high ground temperatures and relatively low upper-air temperatures, results in rising air and moisture supply to the mid- and upper troposphere. This ascent is enhanced orographically in the regions of the Ahggar, Ennedi, and Uweinat mountain ranges. Sounding data indicate that without the presence of a blocking inversion, relative humidity of as little as $\sim 20 \%$ near ground level may generate clouds above the Sahara (Fig. S8). The second possible moisture source is when the Mediterranean and Red Seas supply additional moisture to the plume that converges and precipitates in the Levant. The trajectories characterizing TP and ARST moisture transport are somewhat similar. However, their respective rainfall patterns are quite different, and thus trajectories are insufficient to explain this difference. 


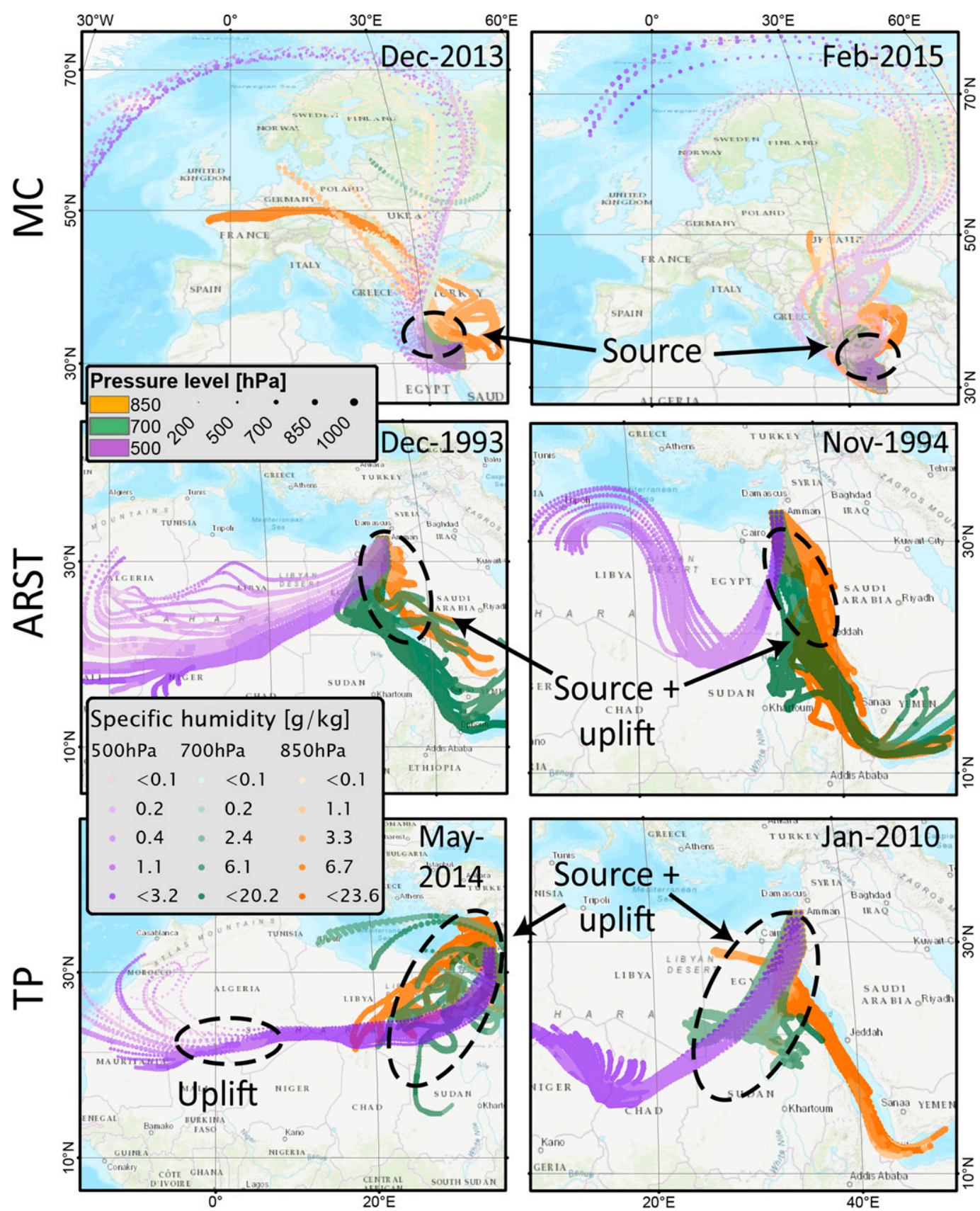

FIG. 2. Back trajectories for the different case studies, $120 \mathrm{~h}$ back from the time of rainfall initiation. The purple color denotes trajectories reaching the study area at the 500-hPa pressure level; green and orange are similar, but for 700 and $850 \mathrm{hPa}$, respectively. Pressure change along the trajectories is demonstrated by symbol size, and specific humidity change is represented by color saturation. Also marked are regions with significant air ascent (denoted "uplift") and those with a major increase in specific humidity ("source"). Time series of pressure, specific humidity, and relative humidity, also used in identifying moisture sources, are shown in Figs. S2-S7.

Analysis of the moisture profile revealed additional differences between synoptic-system dynamics (Fig. 3). The MCs' moisture content was much lower than that in the other two synoptic systems. The average ratio of maximal to minimal TCW during a MC storm was 1.6.
This relatively low moisture content is the result of its colder air mass, originating at midlatitudes, that is often bounded by a cold-frontal/subsidence inversion layer. In ARSTs, the TCW values were quite high before the event and remained high throughout most of the 
rainstorm, with a ratio of 1.3 between high and low peaks. Rainfall from ARST was initiated mostly during the afternoon, and it did not reduce the TCW by much. TCW values during TP storms increased quite rapidly in the 6-12 $\mathrm{h}$ prior to rainfall initiation because of the high moisture flux to the region, comparable to TP and AR events elsewhere (Dacre et al. 2015) (Videos S5, S6). During TP rainstorms, the TCW decreased abruptly to much lower values as a consequence of the continuous lateral moisture flux, and probably more importantly, as a result of the rainfall. The ratio of maximal to minimal $\mathrm{TCW}$ in $\mathrm{TP}$ rainstorms was 2.4 .

\section{b. Rainfall patterns}

The differences in moisture dynamics among the three synoptic-scale systems express different rainfall mechanisms and precipitation efficiencies (defined as the ratio of rainfall mass to moisture influx; Doswell et al. 1996; Sui et al. 2007). The moisture profiles during MC events suggest a moderate precipitation efficiency. Actual precipitating rain cells are small but frequent (Belachsen et al. 2017; Peleg and Morin 2012); the events are relatively long, and there is a continuous moisture supply from the Mediterranean Sea. Thus, rainfall quantities might reach high values over broad regions (Fig. 4a), and only $17 \%$ of the total rainfall amount is convective, that is, with intensity of $>5 \mathrm{~mm} \mathrm{~h}^{-1}$ (Belachsen et al. 2017).

Rather uniform moisture content during ARST events implies a lower precipitation efficiency and a different rainfall-generation mechanism. For the ARST, the mechanism is local (mostly $\leq$ meso- $\beta$ ) and spotty (Figs. $4 \mathrm{~b}, 5 \mathrm{~b}$ ). As it has already been delivered to the Levant, moisture is present throughout the event and is ready to precipitate when conditions are right, for example, by diurnal heating, which causes thermal convection, or through other locally governed factors that include wind-orography interactions. Thus, the convective rain constitutes a much larger portion of the total amount (38\%).

TP rainstorms are characterized by a wide distribution of precipitating clouds (Fig. 5c). Rainfall is distributed over large areas, and high precipitation rates are embedded within broad, moderate-rate regions (Fig. 4c), such that the convective rainfall contribution to the total amount is $31 \%$. Overall rainfall coverage is high throughout the storm. This, together with atmospheric instability, indicates that the rainfall-producing mechanism is regional $(>$ meso- $\beta$ ) in scale and that precipitation efficiency is high, as inferred from the rapid decrease in moisture content following rainfall initiation (Fig. 3). This is likely due to jet-related upper-level divergence (Rubin et al. 2007; Kahana et al. 2002, their Fig. 6).

The catchments affected by the MC storms are situated north of the Negev highlands (north of $30.7^{\circ} \mathrm{N}$; Fig. 6; see also Kahana et al. 2002); thus, the probability of high

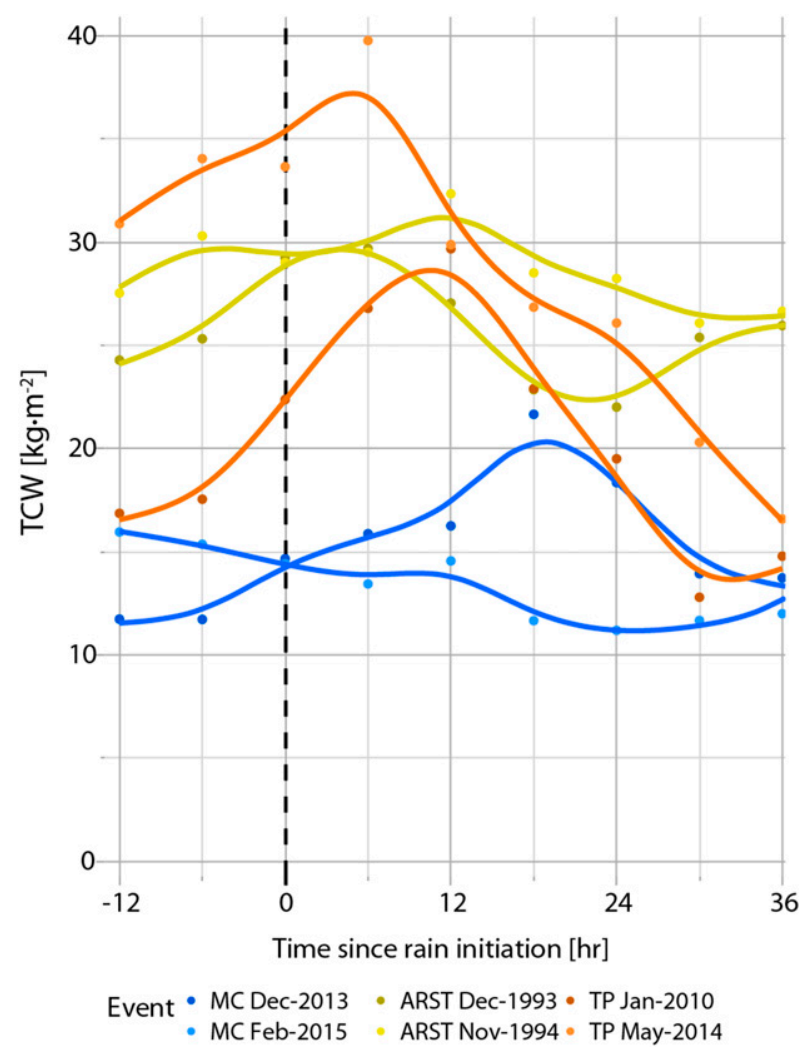

FIG. 3. TCW averaged over the study area, all starting $12 \mathrm{~h}$ prior to significant rainfall initiation in the respective storms. Blue, yellow, and orange lines represent smoothed TCW curves in MC, ARST, and TP storms, respectively. Note the rise in moisture prior to TP storms and its fall a few hours after the rainfall has started, and compare this with the more stable moisture content during $\mathrm{MC}$ and ARST events.

rainfall amounts in the southern Sinai-southern Negev approaches zero, in accordance with Amit et al. (2006). This probability increases northward. As expected, for example, according to Goldreich (1994) and Sharon and Kutiel (1986), rainfall amounts tend to increase when air parcels encounter orographic barriers and decrease in the rain shadow area of the Dead Sea rift valley. This "inverse orographic effect," as termed by Sharon (1979), is an important feature, specifically in the case of the MC storms. East of the rain shadow area, the amount of rainfall increases once again, affected by the upslope flow on the Jordanian Dead Sea escarpment (e.g., Fig. 4a).

High variability in rainfall amounts across the region in ARST rainstorms is due to the highly convective and spotty nature of the precipitation. Rainfall depths may be high over the southern part of the study area and show a slight decrease toward the north (Fig. 6). This is probably because a major portion of the moisture in ARSTs originates at the Red Sea, and thus the mountains block the moisture and rainfall northward in the Levant drylands. 
(a)

(b)

(c)

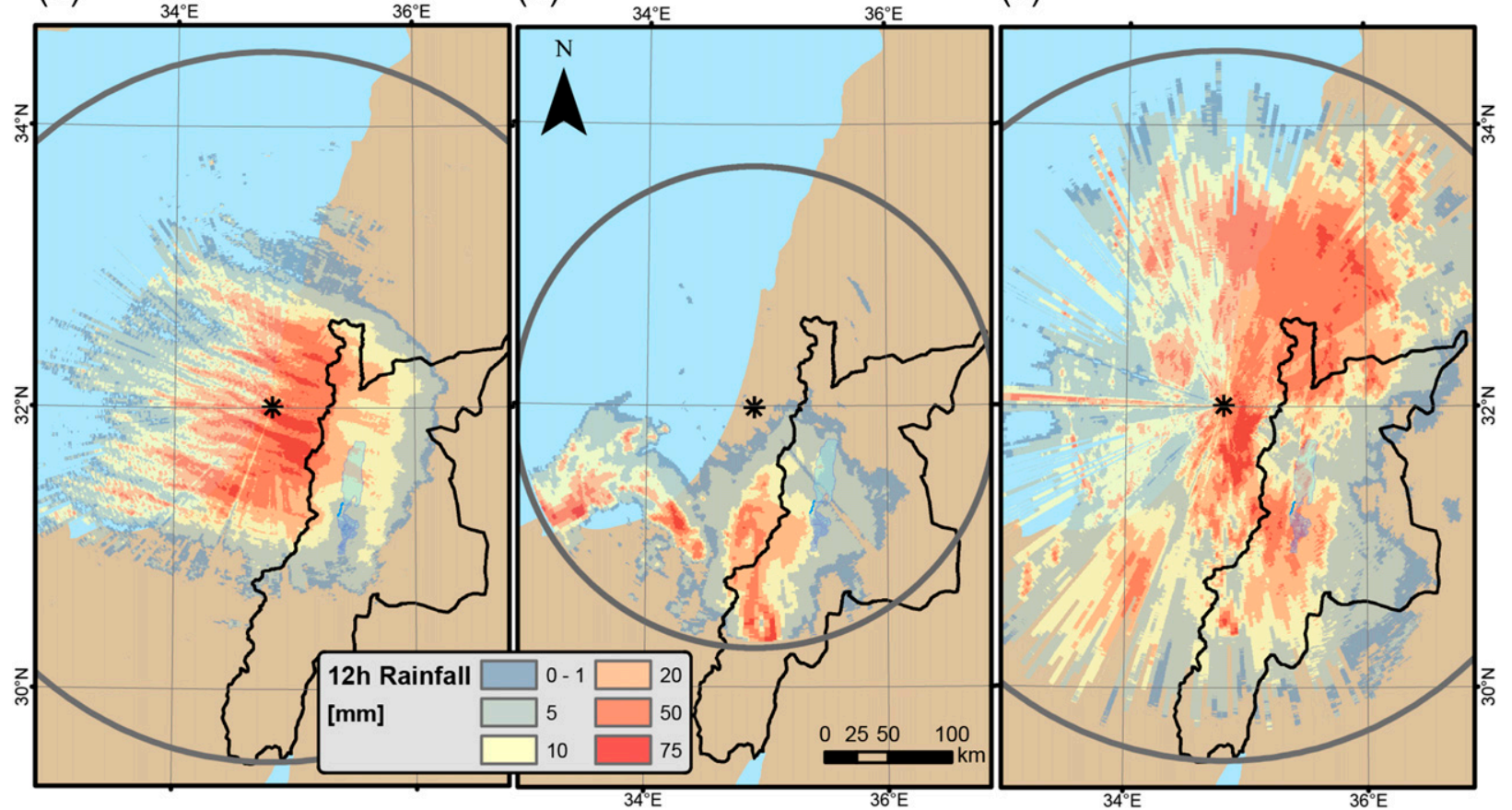

FIG. 4. Rainfall maps for the $12 \mathrm{~h}$ experiencing maximum rainfall (averaged over the entire study area) during storms associated with the three different patterns. The black polygon denotes the study area. Maximum rainfall for $12 \mathrm{~h}$ (a) decreases to the south and east in $\mathrm{MC}$ (13 Dec 2013), (b) is localized in ARST (22-23 Dec 1993), and (c) is widespread in the TP (7-8 May 2014).

In TP events, moisture added from the Mediterranean causes the rainfall amounts to increase northward, but the widespread rainfall generates high amounts in the southern part of the region (Fig. 6), reaching up to $70 \%-100 \%$ of mean annual rainfall in only 1 day in the hyperarid southern Negev (IMS 2016).

Areal coverage of rain depth above different thresholds was examined for different durations (from 0.5 to
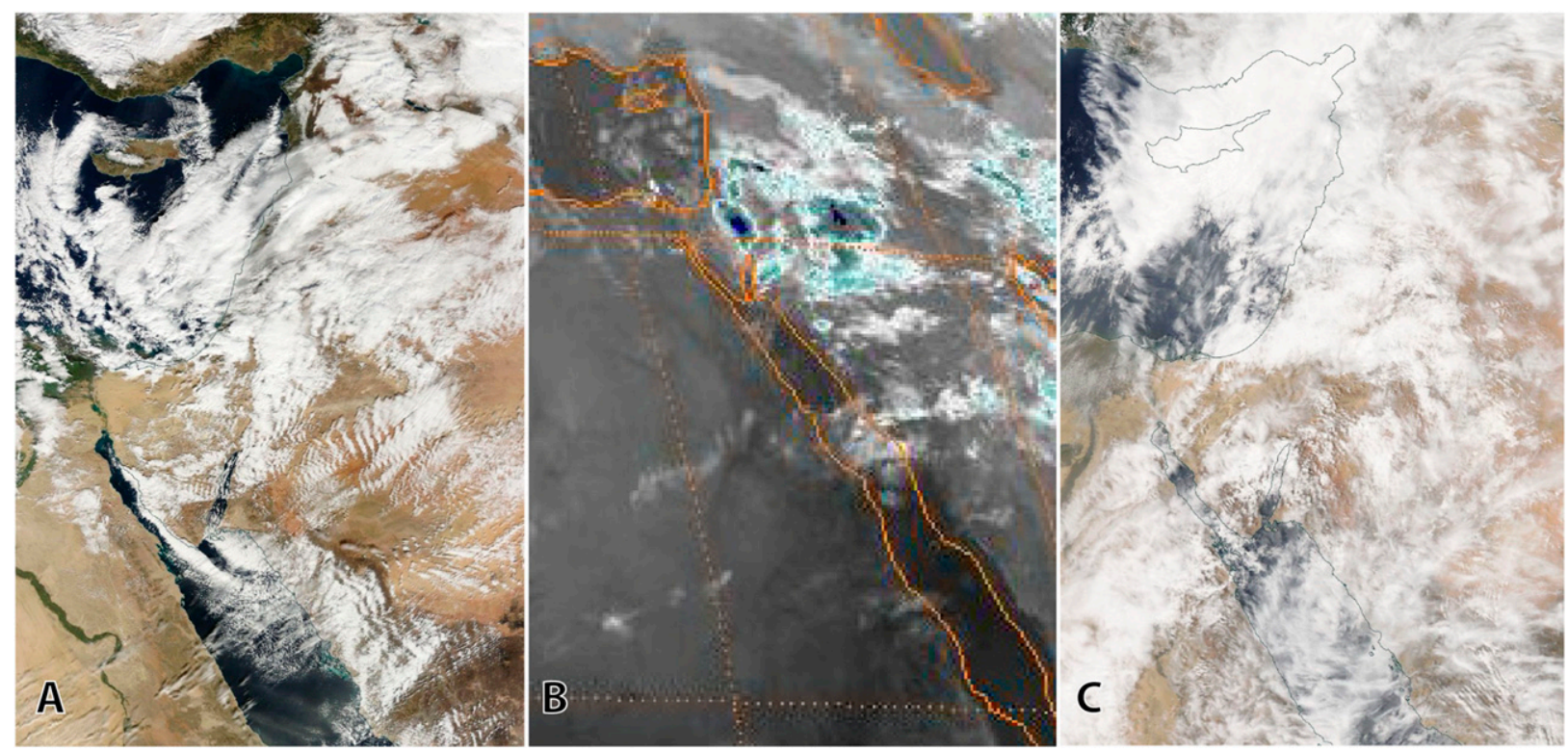

FIG. 5. Example satellite images from three different synoptic systems: (a) MC (12 Dec 2013); (b) ARST (21 Dec 1993), note the local nature of the clouds; and (c) TP (6 May 2014), note the high cloud coverage. Images are from NASA Worldview and ISCCP. 


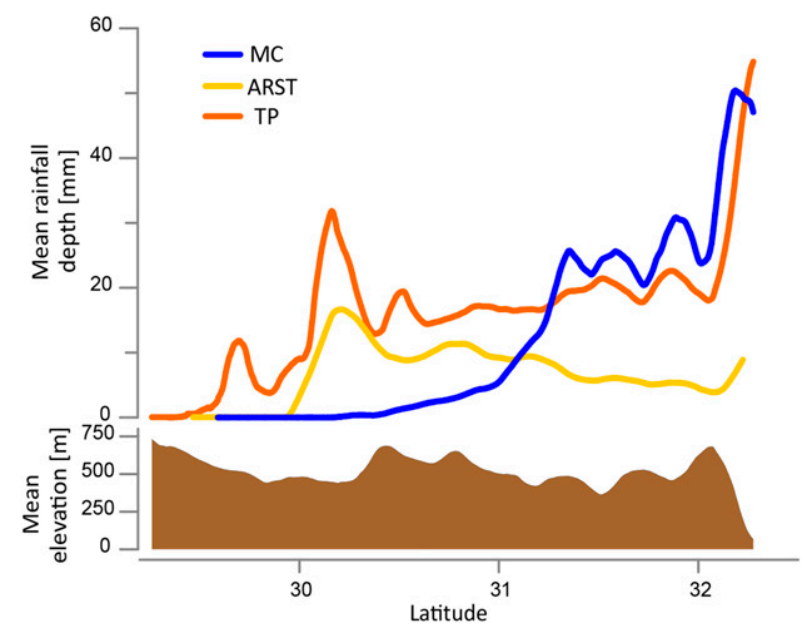

FIG. 6. Latitudinal mean rainfall depth across the study region for the different synoptic types and the mean elevation across these latitudes. North is on the right side.

$48 \mathrm{~h}$ ), where for each duration the storm interval with the maximal mean areal rain depth was considered. Rainfall amounts associated with MC storms increased to some extent with increasing storm duration (Fig. 7). The rainfall consisted of numerous, mostly low- to moderate-magnitude rain cells (also see Belachsen et al. 2017) that generate large rainfall coverage $(40 \%$ of study area received $>5 \mathrm{~mm}$ total rainfall during the $12 \mathrm{~h}$ of maximum rainfall; Fig. 7). Frequent arrival of rain cells to the region could accumulate into large rainfall amounts over long durations (4\% of the study area accumulated $>50 \mathrm{~mm}$ in $24 \mathrm{~h}$ ), and the rainy interval exceeded $48 \mathrm{~h}$ in certain locations.

Rainfall from ARST storms is much shorter in duration (see also Marra and Morin 2018). Thus, rainfall amounts did not increase much with duration (Fig. 7). High-magnitude convective rain cells generated small rainfall coverage, with only $0.1 \%(30 \%)$ of the study area receiving $>50 \mathrm{~mm}(5 \mathrm{~mm})$ rainfall over a 12 -h interval. The rainy interval did not exceed a few hours in most locations. Rainfall amounts were on average much smaller than measured for the other two synoptic systems.

TP events showed high rainfall depths across the entire study region. The precipitation was composed of small, high-intensity rainfall cells embedded in widespread rainfall of moderate intensity. On average, $83 \%$ of the region received $>5 \mathrm{~mm}$ rainfall in $12 \mathrm{~h}$. The highintensity rainfall cells covered $0.7 \%$ of the area with $>50 \mathrm{~mm}$ for $12 \mathrm{~h}$, but the relatively long duration of the storm resulted in $4.6 \%$ coverage for the same intensity during $24 \mathrm{~h}$ (Fig. 7 ), and the rainy interval lasted more than $48 \mathrm{~h}$ over parts of the region.

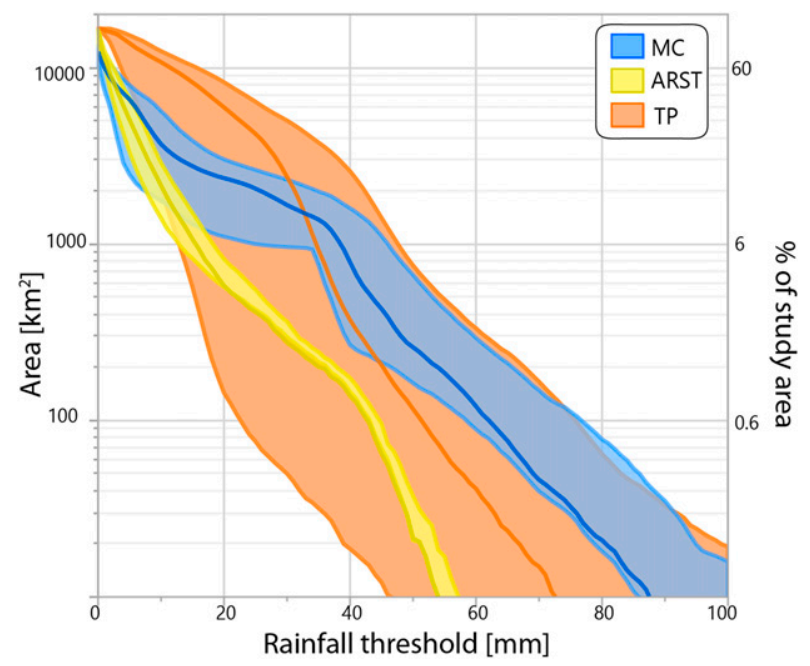

FIG. 7. Areal coverage of rainfall above a range of thresholds in rainfall amount during different types of storms. Presented data are for a minimum 3-h rainfall above a specific threshold (the left boundary of each type). The upper boundary (right edge of the specific colored polygon) is the $24-\mathrm{h}$ rainfall coverage. The respective central lines are the 12 -h areal coverage.

\section{c. Flash flood patterns}

Different synoptic patterns generate different rainfall patterns that trigger flash floods with different hydrographs and regional coverage (Hirschboeck et al. 2000). These differences are demonstrated for three selected hydrographs observed for the analyzed events (Fig. 8). Low-intensity rainfall in $\mathrm{MC}$ events generated mostly low-magnitude (as also indicated by the regional envelope curve of flood maxima; Fig. 9), long-lasting flash floods that were confined to the northern part of the region.

ARST- and TP-generated flash floods could potentially affect the southern Levant with distinct differences. The small, convective rain cells of the ARST rainstorms trigger local flash floods characterized by high instantaneous peak discharge and short rising limbs, but simultaneously activate only a small fraction of the streams (Figs. 8, 9). It should be noted that simultaneous activation of multiple streams by ARST is rare and possibly exaggerated here, since we chose extreme cases with rains prevailing for a few consecutive days. Analyzing a more typical ARST event would probably reveal floods of an even more local nature and highmagnitude flash floods in only a few small catchments.

When compared with the other synoptic-scale patterns, TP-generated floods were high magnitude, simultaneous, for all ranges of catchment sizes, and their respective peaks approached the regional envelope curve for flood magnitudes (Fig. 9). Furthermore, Shentsis et al. (2012) have shown that for the same peak discharge, ARST floods produce much smaller flood volumes compared to MC floods. Our analysis (Figs. 9, 10) 


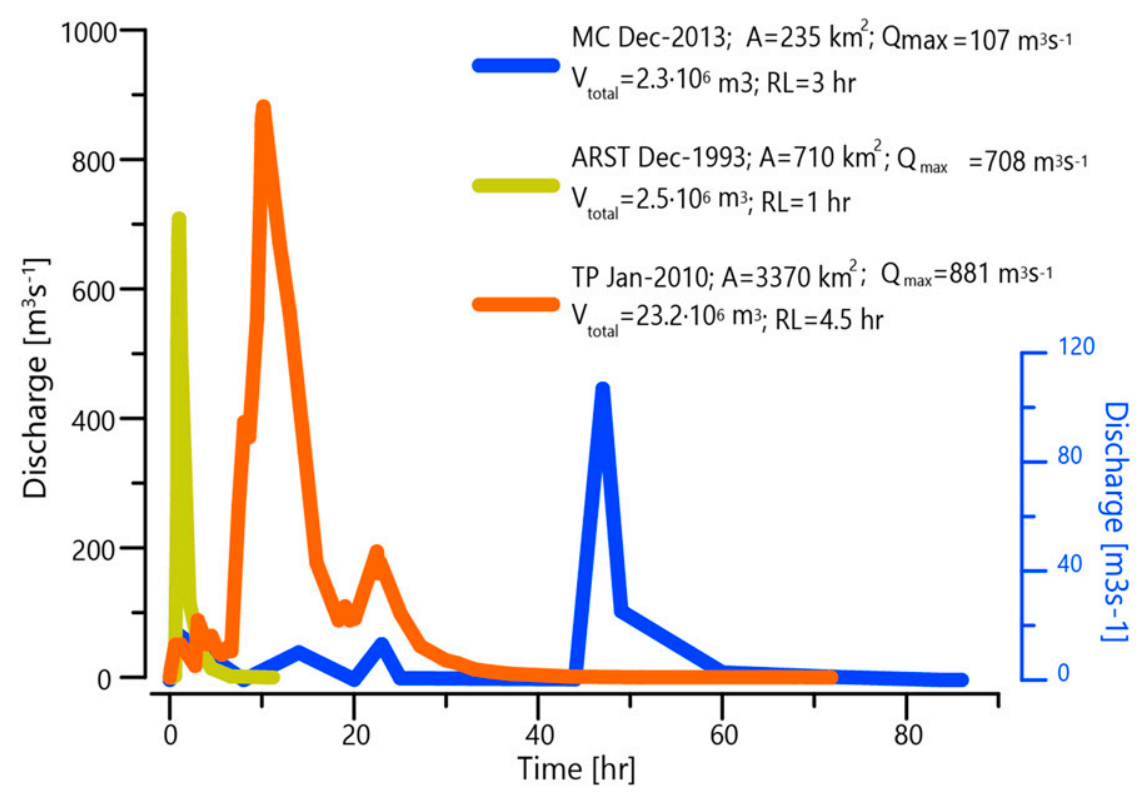

FIG. 8. Hydrographs generated by the three synoptic types as recorded in different catchments: $A$ denotes catchment area, $Q_{\max }$ is maximum basinwide discharge, $V_{\text {total }}$ is total recorded flood volume, and RL is rising-limb duration. Note the expanded scale for MC floods; in the arid parts of the Levant they produce relatively smaller instantaneous peak discharge.

showed that TP floods produce both large flood peak discharge and large flood volume. TP-associated floods were usually characterized by multiple flood peaks and longer flow durations and are thus better suited to transferring large volumes of water across wide stretches of the deserts of the Levant. The volume-to-peak discharge ratio in TP floods surpassed that of the MC floods (Fig. 10). The higher discharge volumes in the former are actually expected; the higher precipitation efficiency implies that much more of the advected moisture is transformed into rainfall as well as into floodwater.

The combination of both higher peak discharge and higher volume in TP floods, generated simultaneously in numerous subcatchments, reveals the higher importance of TP floods in regional hydrology and geomorphology. This importance stands out in the larger catchments in the region; ARST storms are too localized for them to cover these catchments, and MCs have too low of an intensity and are limited mainly to the northern catchments. The TP storms combine high enough intensity (more than $\mathrm{MC}$ ), long duration (longer than ARST), and large aerial coverage (much larger than ARST) with floods generated in many subcatchments that are integrated into large (peak and volume) floods in the larger watersheds.

\section{d. Geomorphic implications of flash floods}

During the analyzed interval (1985-2015), a few sediment plumes were documented floating from the Nahal
HaArava channel mouth over the Dead Sea brines (Table S1). Some of these plumes resulted from ARST (e.g., 24-27 October 2015) or MC (e.g., 10-14 December 2013) floods. However, no noticeable changes in channel morphology were caused by these floods. The main changes in the channel were caused by TP floods in 1991, 2010, and 2014, which also produced large sediment plumes over the Dead Sea.

On 22 March 1991, the large TP flood covered large portions of the floodplain and caused geomorphic changes in the Nahal HaArava channel. A $\sim 1-\mathrm{km}$ long channel section was avulsed, and several gullies were incised near the Dead Sea coast (Fig. 11a). These gullies remained abandoned, and no other flood since then has been high enough to reach the floodplain in this area. In addition, the channel within the Nahal HaArava delta widened significantly (Fig. 11a). Based on the available documentation, the March 1991 flash flood had the largest impact on the morphology of the downstream reach of Nahal HaArava. In contrast to other floods, it resulted in geomorphic changes that remain until today.

As a result of the ongoing incision of the Nahal HaArava channel (Dente et al. 2017), larger flood magnitudes are needed to reach the floodplain, and therefore, the geomorphic effects of regular floods are within the channel, mainly local and temporary. Two subsequent high-magnitude floods (i.e., that reached the floodplain in the upstream reaches) affected the channel. Both were 


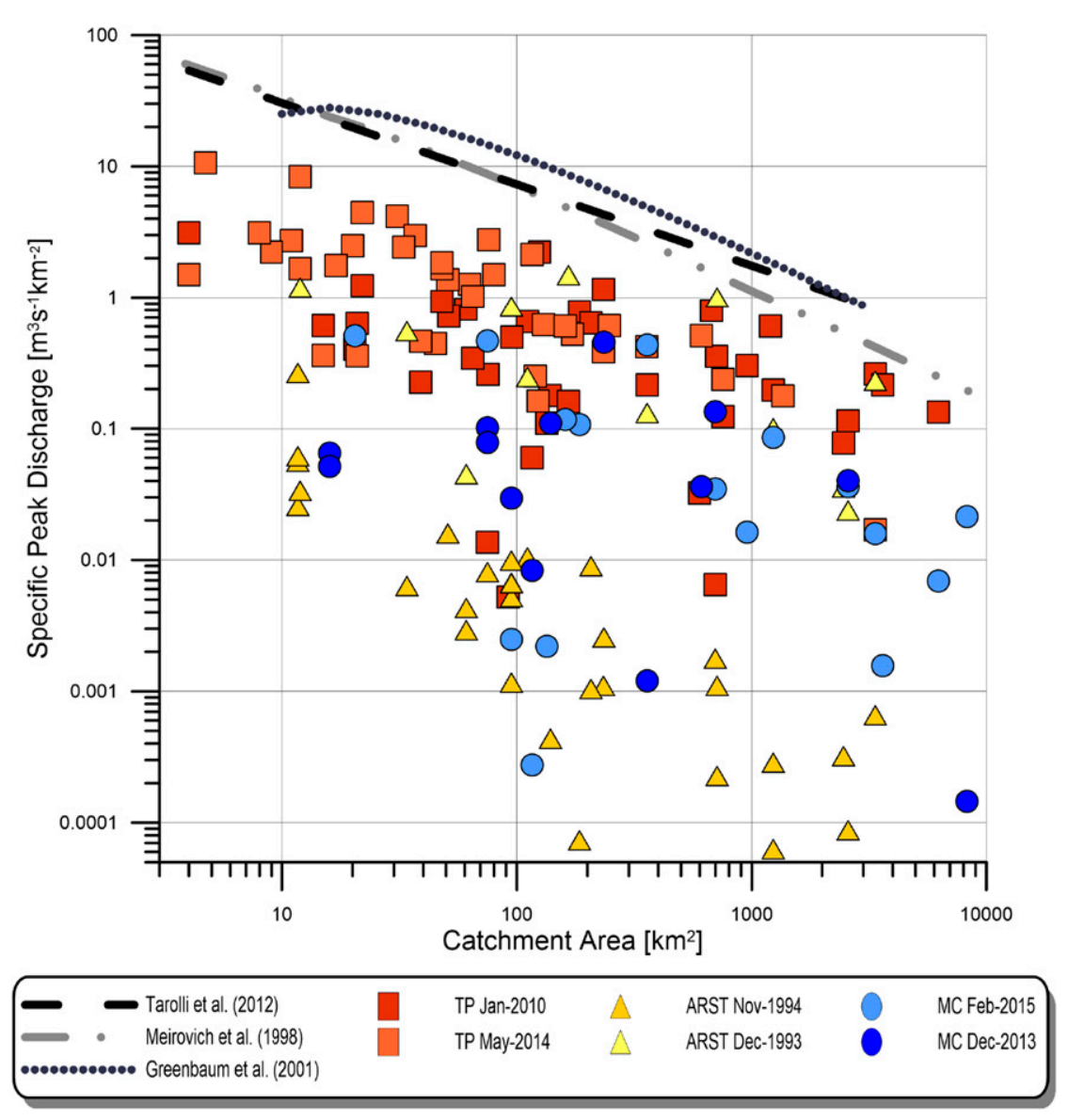

FIG. 9. Relationships between catchment-specific peak discharges in the study area and catchment areas for the six selected storms. The upper dashed lines are different envelope curves developed for the region, with Tarolli et al. (2012) and Meirovich et al. (1998) curves including historical data, and the Greenbaum et al. (2001b) curve also including paleoflood data.

TP-generated floods. The January 2010 flood widened the channel within the delta and a few kilometers upstream, and the channel mouth migrated basinward by $\sim 350 \mathrm{~m}$. To the best of our knowledge and inquiry, the May 2014 TP flood produced the largest documented sediment plume, originating from the south, over the Dead Sea. On 9 May, the plume length reached $\sim 24 \mathrm{~km}$, covering an area of $\sim 140 \mathrm{~km}^{2}$, which is approximately one-quarter of the total Dead Sea surface area (Fig. 11b). This plume might have been even larger, but data from later that day are unavailable. This flood widened several reaches along the channel and caused massive channel bank failures in its delta.

\section{Summary and discussion}

This work examines the relative importance and generation potential of high-magnitude, large-volume floods by the three major flood-producing, synoptic-scale atmospheric circulation patterns that are significant for the hydrogeomorphology of the Levant deserts. We analyzed the hydrometeorology of large rainstorms born from these circulation patterns and their respective flood characteristics. Then, we evaluated the relative importance of these patterns in imposing geomorphic changes and delivering sediment and water through the largest southern tributary to the Dead Sea.

To understand flood-causing processes, separating the floods according to the concurrent atmospheric circulation is a first-order process (Hirschboeck 1987; Ely et al.1994), especially in climatic transition zones such as the Levant, because floods in such regions are born from a mixed population of synoptic-scale and mesoscale processes. The three synoptic patterns have distinct hydrometeorological characteristics (Table 2). They differ in moisture origins and dynamics, total rainfall amount, intensity, duration, and spatial distribution (basin coverage). Therefore, they have distinct 


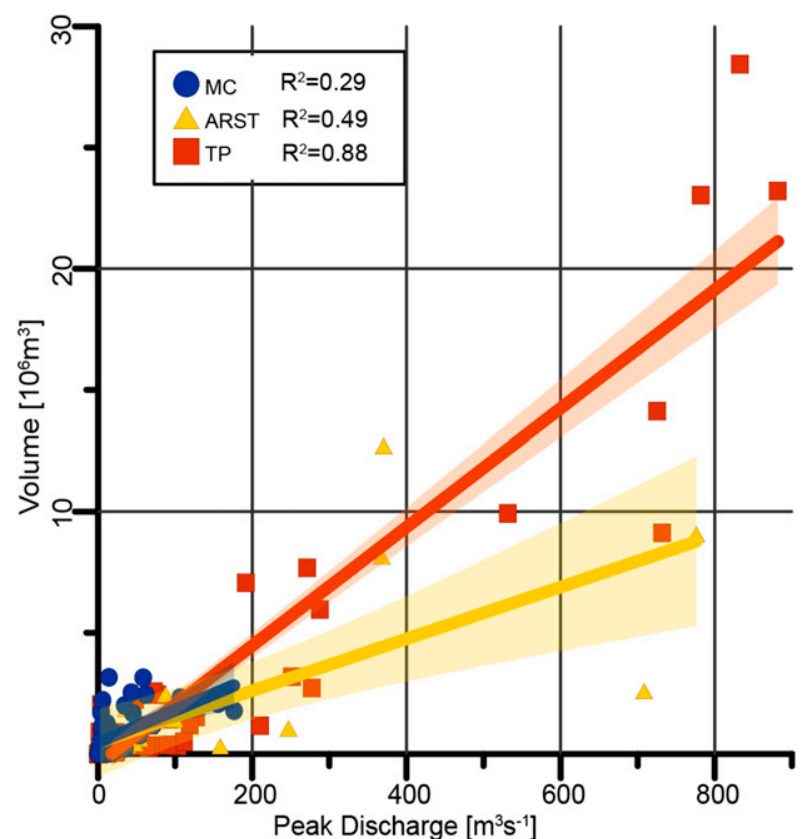

FIG. 10. Total flood volume vs peak discharge from all available data for the six case studies. Linear regressions with $95 \%$ confidence boundaries are drawn as well, with their corresponding $R^{2}$ values.

differences in the characteristics of their respective flood peaks and total discharge. The identified characteristics were derived in the present study through a detailed analysis of six case studies representing the different synoptic systems. The case studies were selected using strict criteria to ensure the quality and extremeness of the events. Further investigation is required to better understand the sensitivity of flood magnitude and patterns to the synoptic-scale characteristics using, for example, event simulations with high-resolution numerical weather models (e.g., Smith et al. 2011a; Deng et al. 2015).

MC rainstorms draw moisture from the eastern Mediterranean and convert it to rainfall over broad areas. Although they affect and control the past and present-day northern Levant climate and are capable of generating relatively high-volume floods (Ziv et al. 2006; Enzel et al. 2003, 2008; Kushnir et al. 2017), their impact diminishes to the south and affects mainly the northernmost edge of the Levant deserts. ARST events are supplied by moisture that is mostly from the Red Sea. This moisture then precipitates owing to local-scale forcing, which results in high rainfall amounts over relatively small watersheds and scattered, high-peak-discharge, small-volume floods in catchments $<10^{3} \mathrm{~km}^{2}$, or low-magnitude floods in catchments of all sizes, over short durations.

TPs transfer moisture across the Sahara to the Levant, generating relatively long-duration ( $\sim 2$ days), large-scale rainstorms, including in the hyperarid southern Negev,
Sinai, and southern Jordan (and northwestern Arabia and Eastern Desert of Egypt). This results in broad, highpeak-discharge and high-volume floods in many streams simultaneously. These floods, in many small and medium catchments, integrate, resulting in high-magnitude floods in the larger catchments $\left(10^{3}-10^{4} \mathrm{~km}^{2}\right)$, similar to other regions, and not necessarily only in drylands (e.g., O'Connor and Costa 2004). Thus, they are more likely to influence the regional hydrology (in our case, for example, delivering noticeable discharge to the Dead Sea) and long-lasting geomorphic changes. These extreme storms and floods play a major role in the Levant drylands through a variety of processes, such as channel evolution (Salomon et al. 2016); sediment production, transport, and deposition; terrace aggradation and erosion (Enzel et al. 2012); filling of lowlands with sediment and water (Enzel et al. 2008; Torfstein et al. 2015); and accelerated sinkhole formation (Avni et al. 2016). They may also cause infrastructure damage and even loss of life (Farhan and Anbar 2014; Dayan and Abramski 1983; Borga and Morin 2014). Considering discharge into the Dead Sea from its southern tributaries, these TP winter storms may be the generators of any significant water volume.

Here we showed, for a set of documented floods, that TP-generated floods lead to the most significant geomorphic changes in the downstream reaches of Nahal HaArava. It is therefore plausible that a similar storm type triggered floods (and thus hydrogeomorphic work) in the recent and more distant past and may be important to paleoenvironmental and paleohydrological inferences from the Dead Sea records. The other synoptic systems generate floods that occasionally do reach the mouth of Nahal HaArava and transport sediment into the Dead Sea. However, modern observations indicate that ARST and MC floods have had only minimal and, in most cases, unnoticeable geomorphic changes in the downstream reaches of the Nahal HaArava channel. It should be emphasized that the geomorphic analysis presented here focuses only in Nahal HaArava, the largest stream in the southern Dead Sea region, and therefore can be applied to deduce about the larger and southern streams in the region.

Associating fluvial geomorphic changes with climate changes is a common long-term assumption and practice (e.g., Mabbutt 1977; Enzel et al. 2012; Bull and Schick 1979; Wolman and Gerson 1978; Anders et al. 2005), but is difficult to support with quality data. It is even more difficult to associate geomorphic changes to specific atmospheric circulation patterns. Regional hydrogeomorphic responses in the southern Levant, as in many other regions of the world, have yet to be determined. Such responses are usually studied through anecdotal case studies, which are difficult to generalize. In the Levant, 

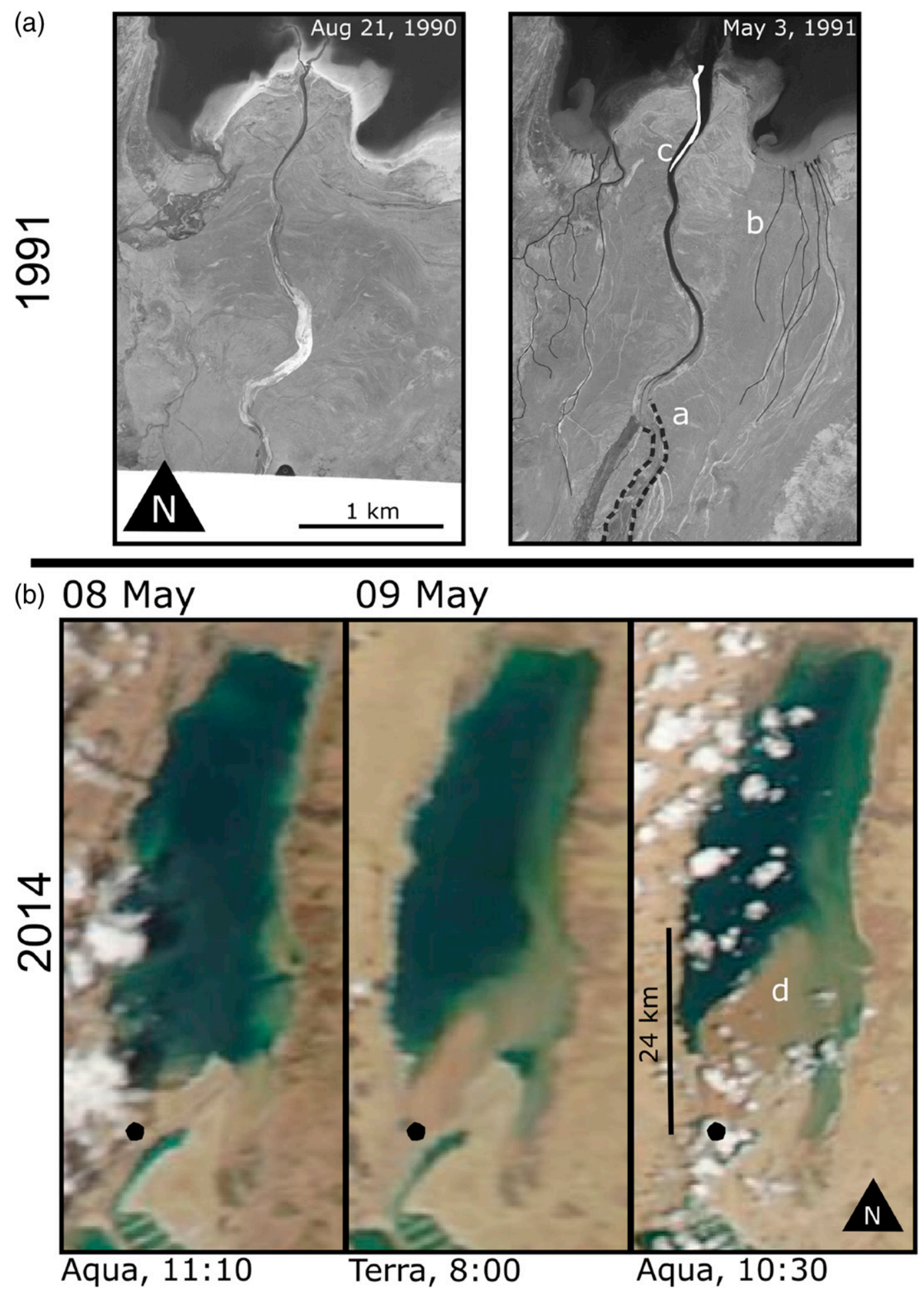

FIG. 11. Effects of (a) March 1991 (in aerial photographs) and (b) May 2014 (in MODIS true color imagery) flash floods in Nahal HaArava. Label " $\mathrm{a}$ " shows avulsion of a $\sim 1-\mathrm{km}$ segment $300 \mathrm{~m}$ to the west (the abandoned segment is marked with dashed lines). Label " $b$ " shows incised gullies (marked by gray lines) from east and west of the main channel. Label "c" shows widening of the main channel near the mouth (the extent of the preflood channel is marked with a white polygon). Label "d" shows the largest documented sediment plume from Nahal HaArava between 1985 and 2015, produced during the May 2014 flood. The black dot indicates the Nahal HaArava mouth in 2014. 
TABLE 2. Summary of main characteristics of the different types of synoptic systems.

\begin{tabular}{|c|c|c|c|c|}
\hline \multirow[b]{2}{*}{$\begin{array}{l}\text { Synoptic } \\
\text { system }\end{array}$} & \multicolumn{4}{|c|}{ Aspect } \\
\hline & $\begin{array}{l}\text { Meteorology: moisture } \\
\text { sources and dynamics }\end{array}$ & $\begin{array}{l}\text { Meteorological } \\
\text { response: rainfall }\end{array}$ & $\begin{array}{l}\text { Hydrology: maximal } \\
\text { discharge and flow volume }\end{array}$ & $\begin{array}{l}\text { Geomorphic response: } \\
\text { Nahal HaArava }\end{array}$ \\
\hline $\mathrm{MC}$ & $\begin{array}{l}\text { Mediterranean source, low } \\
\text { absolute moisture }\end{array}$ & $\begin{array}{l}\text { High areal coverage by } \\
\text { low-intensity rainfall } \\
\text { in northern parts of } \\
\text { the region, low coverage } \\
\text { by high-intensity rainfall, } \\
\text { decreasing southward }\end{array}$ & $\begin{array}{l}\text { Mainly in northern catchments, } \\
\text { low peak discharge }\end{array}$ & $\begin{array}{l}\text { No substantial flow and } \\
\text { thus small sediment } \\
\text { plumes, no channel } \\
\text { changes }\end{array}$ \\
\hline ARST & $\begin{array}{l}\text { Red Sea source, high } \\
\text { amounts of moisture, } \\
\text { local-scale forcing } \\
\text { (thermal convection), } \\
\text { low precipitation efficiency }\end{array}$ & $\begin{array}{l}\text { Short-duration, high- } \\
\text { intensity rainfall with } \\
\text { low coverage }\end{array}$ & $\begin{array}{l}\text { A few catchments at once, high } \\
\text { peak discharge and low } \\
\text { volume, mainly in small to } \\
\text { medium catchments; large } \\
\text { variability-most catchments } \\
\text { are not activated }\end{array}$ & $\begin{array}{l}\text { Usually no flow. At } \\
\text { times, mostly small } \\
\text { sediment plumes, no } \\
\text { significant changes in } \\
\text { stream channel/delta }\end{array}$ \\
\hline TP & $\begin{array}{l}\text { Distant (W-SW) source in } \\
\text { middle-upper levels, and } \\
\text { added moisture from } \\
\text { Mediterranean and Red } \\
\text { seas in the lower level, } \\
\text { high moisture content, } \\
\text { large-scale forcing } \\
\text { (STJ divergence), high } \\
\text { precipitation efficiency }\end{array}$ & $\begin{array}{l}\text { Long-duration, moderate- } \\
\text { intensity rainfall, high } \\
\text { coverage throughout } \\
\text { the region }\end{array}$ & $\begin{array}{l}\text { High peak discharge on all } \\
\text { catchment scales (including } \\
\text { largest and most arid catchments). } \\
\text { High volume to discharge ratio, } \\
\text { very high-volume and high- } \\
\text { discharge floods }\end{array}$ & $\begin{array}{l}\text { High flow and thus large } \\
\text { sediment plumes, } \\
\text { channel widening, } \\
\text { flooding of floodplain, } \\
\text { avulsion, gully incision, } \\
\text { dissolution of the delta }\end{array}$ \\
\hline
\end{tabular}

these studies have focused on the last 2000 years, such as studies of paleofloods in the Zin watershed (Greenbaum et al. 2000, 2001b) or Arava catchment (Greenbaum et al. 2001a). Other studies have focused mainly on smaller catchments in the hyperarid southern Negev, such as Nahal Yael (Enzel et al. 2012) and Nahal Netafim (Greenbaum et al. 2006b), or on the impact of rainfall and lake-level drop of the Dead Sea on channel incision and sediment transport (Ben Moshe et al. 2008; Davis et al. 2009; Salomon et al. 2016). None of these studies has successfully related direct, large-scale, climatic changes and atmospheric patterns to geomorphic changes in the fluvial system throughout the southern Levant. This might be because synoptic-scale watershed relationships involve too many parameters that are unknown, or whose combinations produce a complicated, nonlinear, and nonsynchronous response (e.g., Benito et al. 2015). However, when analyzing the extremes, specific atmospheric patterns seem to emerge for flood generation (e.g., Enzel et al. 1989, 1992; Ely et al. 1994), which could potentially be the causes of the geomorphic response.

It has been proposed that southern Levant deserts were affected during Pleistocene and Holocene intervals by large enough rainstorms and floods under different climates to alter the regional environment and hydrology (e.g., Kushnir et al. 2017; Bartov et al. 2003; Enzel et al. 2008; Torfstein et al. 2015). Studying present-day, extreme hydrometeorological events may provide insights into the proposed past intervals of increased flash flood frequency characterized by episodes of marked hydrogeomorphic work (e.g., Greenbaum et al. 2001b; Enzel et al. 2012; Clapp et al. 2000). This might be elaborated by linking hydrological regime and causative synoptic type via distinguishing between processes that presently affect the smallest to largest catchments.

Increased frequency of each of the flood-producing synoptic patterns would have had a different outcome. Increased frequency of MCs (on seasonal to multiannual scales) would have increased rainfall in the northern parts of the study region and would have caused higher-volume, low-peak-discharge floods. This would have caused 1) substantial water influx to the Dead Sea from the northern watershed, 2) increased flooding and sediment delivery to the lake from its eastern and western margins, and 3) only minimal volume and magnitude floods from the southern catchments to the lake. To generate substantial sediment flux in these southern streams, flood discharge, and the resultant stream power, would have had to increase (e.g., Costa and O'Connor 1995; Wolman and Miller 1960), but this might not have been possible for the MC floods with their low instantaneous peak discharge.

On the other hand, increased frequency of ARST storms would have increased intermittent, high-peakdischarge floods, which would have activated isolated small- to medium-size catchments scattered throughout the region. Such floods could have been locally large, but 
with their short peak discharge, they would have been characterized by low volume. Their sediment yield in the larger streams would have been relatively low as well and more pronounced in high-gradient streams (e.g., Salomon et al. 2016; Alexandrov et al. 2003).

Increased TP frequency would have resulted in flash floods of both high peak discharge and volume, with widespread, simultaneous activation of numerous streams in a wide range of catchment sizes. This would have diminished the discontinuity of water and sediment, characteristic of the southern Levant watersheds and increased the fraction of water reaching the Dead Sea from its hyperarid southern tributaries. This, in turn, would have increased sediment delivery by these southern streams to the lake. This integration of flow with high peak and volume would have been most able to affect the geomorphology of the larger streams in the southern Levant.

Both TPs and ARs are situated west of an extratropical cyclone and involve high moisture flux (e.g., Dacre et al. 2015; Knippertz 2007). Analogous increase in the frequency of ARs, as proposed above, was found to be important in the western United States. Modern analogs for circulation patterns that cause the largest Holocene floods in large watersheds of the southwestern United States were proposed (Enzel et al. 1989, 1992; Ely et al. 1994; Kirby et al. 2012), and many of them were associated with ARs - the cause for the largest floods presently (e.g., Barth et al. 2017; Konrad and Dettinger 2017). The largest difference between the worldwide phenomenon of flash floods triggered by ARs (Ralph et al. 2017) and the Levant TPs is the lower-atmosphere moisture content. While most of the ARs are accompanied by high moisture content in the lowest $3 \mathrm{~km}$ of the atmosphere, TPs originating southwest of the Levant are relatively dry in the lower atmosphere, because of the dry Saharan desert. Thus, Levant TPs are based mainly on the STJ moisture supply above the planetary boundary layer (Rubin et al. 2007), and therefore many of the TPs do not precipitate at all (Tubi and Dayan 2014).

Although scarce today, TPs are significant features in present-day climate, especially in the hyperarid southern Levant and drylands farther south that are rarely affected by Mediterranean moisture (Kahana et al. 2002; Ziv 2001; Rubin et al. 2007; Farhan and Anbar 2014; de Vries et al. 2016; Enzel et al. 2015; Tubi and Dayan 2014; Barth and Steinkohl 2004). Throughout the Holocene and late Pleistocene, rainfall-rich intervals occasionally prevailed in the Levant, resulting in high-magnitude floods and dynamic sediment production and transport (Enzel et al. 2003, 2015; Greenbaum et al. 2006b; Enzel et al. 2008; Greenbaum et al. 2000; Vaks et al. 2006).

The geochemistry of large fossil aquifers in the Sahara, Negev, and Arabian Deserts presents evidence for past wetter intervals regionally (Abouelmagd et al. 2012; Vengosh et al. 2007; Issar et al. 1972). There have been a few hypotheses regarding their ages and, more importantly, their sources. The question of source is directly related to the potential moisture sources and the transporting atmospheric circulation patterns. For example, the isotopic composition of rainfall sourced in West Africa (eastern Atlantic Ocean and the ITCZ) is most suitable for explaining the isotopic composition of fossil water in the Western Desert of Egypt, which is part of the Sahara (Abouelmagd et al. 2012, 2014; Sonntag et al. 1980). This emphasizes the importance of TPs in the past as a synoptic-scale pattern that could actually bring such moisture to the region. Moisture supply from equatorial Africa or the eastern Atlantic Ocean to the Levant is possible under a forceful, distinct STJ streak to the north of the region. This occurs when the STJ streak is oriented to the northeast (or east-northeast) and bends ahead of a south-penetrating upper-troposphere trough (Dayan and Abramski 1983; Tubi and Dayan 2014; Rubin et al. 2007; Knippertz 2005). The moisture source identified here (Fig. 2) in TP storms suggests that it would probably be more difficult to isotopically pinpoint these events in the Levant, as in this region moisture is also pulled from the Red and Mediterranean Seas. Even with this problem and the scarce information on fossil aquifers in the southern Levant (Arava valley), a depleted isotopic signature, enriched in the northwestern direction, exists in the younger parts of the fossil aquifer; this might indicate a water source similar to that suggested for the Western Desert (Vengosh et al. 2007).

Necessary conditions to generate TP storms include tropical convection and extratropical lows driven by the STJ that also serve as a conveyor for the moisture (e.g., Knippertz 2007; Rubin et al. 2007). Thus, an increase in the frequency of either of these could potentially increase TP occurrences in the Levant and its southern drylands. Skinner and Poulsen (2016) claimed that the increase in convective activity in West Africa caused an increase in TP occurrences (in autumn) in the Western Sahara during the African humid period $(\sim 14.8-5.5 \mathrm{ka} \mathrm{BP})$. They also showed that this increase is less effective toward the Levant drylands. This change in the moisture source area indicates that in the Levant, away from the source area, across the Sahara, the limiting factor for increased TP occurrence is the STJ activity, that is, considering the great distance between the moisture source (western Africa) and the target rainfall area (the southern Levant), enhanced convection alone is most probably an insufficient explanation for the Levant. However, increased STJ activity above the Sahara, steered southward by an extratropical trough (Knippertz 2005), is a more reasonable explanation for increased occurrence of TP storms in the Levant. 
Levant TP rainstorms occur mostly in winter (with lower frequency in spring and even lower frequency in autumn). This is because they require a strong southwesterly STJ over the Sahara (Rubin et al. 2007; Tubi and Dayan 2014). In summer, the STJ weakens and moves northward, and monsoonal rainfall events are highly localized in northern-equatorial latitudes; they do not extend toward the Levant. In contrast to TPs, in summer, moist air does not travel above the planetary boundary layer (Saaroni and Ziv 2000). Hence, TPrelated rainfall was and is primarily a winter phenomenon, generating hydrological and geomorphic changes during intervals of increased jet-stream activity. This could have occurred, for example, during the last glacial maximum (Maley 2000; Abouelmagd et al. 2012; Ludwig et al. 2016) or during other intervals with increased, probably winter STJ activity, or with a major southward shift of the eddy-driven jet that may also contribute to TP formation (Dayan and Abramski 1983; Merz et al. 2015). This should be further evaluated using robust climatic-meteorological models.

\section{Conclusions}

The main conclusions of this paper are as follows:

- The three major synoptic circulation patterns in the drylands of the Levant significantly differ in their hydrometeorological properties (Table 2).

- MCs draw their moisture from the Mediterranean, convert it to low-intensity rainfall in the northern part of the region, and may generate low-peak-discharge floods.

- ARSTs bring large amounts of moisture to the region, but only a small portion of it is converted to highintensity (low precipitation efficiency), localized rainfall that generates a few scattered floods with high peak discharge and low volume.

- TPs transfer moisture from distant southwest origins over the Sahara. Moisture is efficiently converted into high-spatial-extent, moderate-intensity rainfall that produces numerous simultaneous floods of high peak discharge and volume. These floods trigger geomorphic responses in the region's largest catchment, manifested in large sediment plumes and geomorphic changes in the channel.

- An increase in the frequency of TP rainstorms may generate major hydrogeomorphic changes, focused on the drier parts of the region. Indications of increased TP frequency in the past emphasize the importance of this synoptic-scale pattern.

- Interactions between STJ and tropical convection indicate that such an increase would be a prominent feature during periods of increased, southerly situated and southwesterly oriented STJ.
Acknowledgments. This study is a contribution to the PALEX project "Paleohydrology and Extreme Floods from the Dead Sea ICDP Core," funded by the DFG (Grant BR2208/13-1/-2). It is also partially funded by the Israel Science Foundation (1007/15), the NSF-BSF (BSF 2016953), the Israel Ministry of Science and Technology, and the Advanced School for Environmental Studies at the Hebrew University of Jerusalem, and is a contribution to the HyMeX program. IMS radar and rain gauge data were provided and preprocessed by the Israel Meteorological Service (ims.gov.il). Shacham radar data were provided by EMS-Mekorot projects (emsmekorotprojects. com). Discharge data were provided by the Israeli hydrological service of the Israeli Water Authority. Aerial photographs were provided by the Geological Survey of Israel (gsi.gov.il/eng/). The authors also thank Francesco Marra, Yair Rinat, and Idit Belachsen for fruitful discussions, and Prof. Lisa Ely and an anonymous reviewer for providing helpful comments on the manuscript. The authors have no conflict of interest to declare.

\section{REFERENCES}

Abouelmagd, A., M. Sultan, A. Milewski, A. E. Kehew, N. C. Sturchio, F. Soliman, R. V. Krishnamurthy, and E. Cutrim, 2012: Toward a better understanding of palaeoclimatic regimes that recharged the fossil aquifers in North Africa: Inferences from stable isotope and remote sensing data. Palaeogeogr. Palaeoclimatol. Palaeoecol., 329-330, 137-149, https://doi.org/10.1016/j.palaeo.2012.02.024.

_ , and Coauthors, 2014: Paleoclimate record in the Nubian Sandstone Aquifer, Sinai Peninsula, Egypt. Quat. Res., 81, 158-167, https://doi.org/10.1016/j.yqres.2013.10.017.

Ahlborn, M., and Coauthors, 2018: Increased frequency of torrential rainstorms during a regional late Holocene eastern Mediterranean drought. Quat. Res., 89, 425-431, https:// doi.org/10.1017/qua.2018.9.

Alexandrov, Y., J. B. Laronne, and I. Reid, 2003: Suspended sediment transport in flash floods of the semiarid northern Negev, Israel. IAHS Publ., 278, 346-352, http://hydrologie.org/ redbooks/a278/iahs_278_346.pdf.

Alpert, P., and Y. Shay-El, 1994: The moisture source for the winter cyclones in the eastern Mediterranean. Isr. Meteor. Res. Pap., 5, 20-27.

—, I. Osetinsky, B. Ziv, and H. Shafir, 2004: Semi-objective classification for daily synoptic systems: Application to the eastern Mediterranean climate change. Int. J. Climatol., 24, 1001-1011, https://doi.org/10.1002/joc.1036.

Amit, R., Y. Enzel, and D. Sharon, 2006: Permanent Quaternary hyperaridity in the Negev, Israel, resulting from regional tectonics blocking Mediterranean frontal systems. Geology, 34, 509-512, https://doi.org/10.1130/G22354.1.

Anders, M. D., and Coauthors, 2005: Pleistocene geomorphology and geochronology of eastern Grand Canyon: Linkages of landscape components during climate changes. Quat. Sci. Rev., 24, 2428-2448, https://doi.org/10.1016/j.quascirev.2005.03.015.

Ashbel, D., 1938: Great floods in Sinai Peninsula, Palestine, Syria and the Syrian Desert, and the influence of the Red Sea on their formation. Quart. J. Roy. Meteor. Soc., 64, 635-639, https://doi.org/10.1002/qj.49706427716. 
Avni, Y., and Coauthors, 2016: Self accelerated development of salt karst during flash floods along the Dead Sea Coast, Israel. J. Geophys. Res. Earth Surf., 121, 17-38, https://doi.org/ 10.1002/2015JF003738.

Bárdossy, A., and F. Filiz, 2005: Identification of flood producing atmospheric circulation patterns. J. Hydrol., 313, 48-57, https://doi.org/10.1016/j.jhydrol.2005.02.006.

Barth, H.-J., and F. Steinkohl, 2004: Origin of winter precipitation in the central coastal lowlands of Saudi Arabia. J. Arid Environ., 57, 101-115, https://doi.org/10.1016/S0140-1963(03)00091-0.

Barth, N. A., G. Villarini, M. A. Nayak, and K. White, 2017: Mixed populations and annual flood frequency estimates in the western United States: The role of atmospheric rivers. Water Resour. Res., 53, 257-269, https://doi.org/10.1002/2016WR019064.

Bartov, Y., S. L. Goldstein, M. Stein, and Y. Enzel, 2003: Catastrophic arid episodes in the eastern Mediterranean linked with the North Atlantic Heinrich events. Geology, 31, 439-442, https://doi.org/ 10.1130/0091-7613(2003)031<0439:CAEITE $>2.0 . C O ; 2$.

Begin, Z. B., M. Stein, A. Katz, M. Machlus, A. Rosenfeld, B. Buchbinder, and Y. Bartov, 2004: Southward migration of rain tracks during the last glacial, revealed by salinity gradient in Lake Lisan (Dead Sea rift). Quat. Sci. Rev., 23, 1627-1636, https://doi.org/10.1016/j.quascirev.2004.01.002.

Belachsen, I., F. Marra, N. Peleg, and E. Morin, 2017: Convective rainfall in a dry climate: Relations with synoptic systems and flash-flood generation in the Dead Sea region. Hydrol. Earth Syst. Sci., 21, 5165-5180, https://doi.org/10.5194/hess-21-5165-2017.

Benito, G., M. G. Macklin, C. Zielhofer, A. F. Jones, and M. J. Machado, 2015: Holocene flooding and climate change in the Mediterranean. Catena, 130, 13-33, https://doi.org/10.1016/ j.catena.2014.11.014.

Ben Moshe, L., I. Haviv, Y. Enzel, E. Zilberman, and A. Matmon, 2008: Incision of alluvial channels in response to a continuous base level fall: Field characterization, modeling, and validation along the Dead Sea. Geomorphology, 93, 524-536, https:// doi.org/10.1016/j.geomorph.2007.03.014.

Borga, M., and E. Morin, 2014: Characteristics of flash flood regimes in the Mediterranean region. Storminess and Environmental Change Climate Forcing and Responses in the Mediterranean Region, N. Diodato and G. Bellocchi, Eds., Springer, 65-76.

Bull, W. B., 1988: Floods; degradation and aggradation. Flood Geomorphology, V. R. Baker, R. C. Kochel, and P. C. Patton, Eds., John Wiley and Sons, 157-165.

- , and A. P. Schick, 1979: Impact of climatic change on an arid watershed: Nahal Yael, southern Israel. Quat. Res., 11, 153171, https://doi.org/10.1016/0033-5894(79)90001-2.

Clapp, E. M., P. R. Bierman, A. P. Schick, J. Lekach, Y. Enzel, and M. Caffee, 2000: Sediment yield exceeds sediment production in arid region drainage basins. Geology, 28, 995-998, https:// doi.org/10.1130/0091-7613(2000)28<995:SYESPI > 2.0.CO;2.

Costa, J. E., and J. E. O'Connor, 1995: Geomorphically effective floods. Natural and Anthropogenic Influences in Fluvial Geomorphology, Geophys. Monogr., Vol. 89, Amer. Geophys. Union, 45-56.

Dacre, H. F., P. A. Clark, O. Martinez-Alvarado, M. A. Stringer, and D. A. Lavers, 2015: How do atmospheric rivers form? Bull. Amer. Meteor. Soc., 96, 1243-1255, https://doi.org/ 10.1175/BAMS-D-14-00031.1.

Davis, M., A. Matmon, E. Zilberman, N. Porat, D. Gluck, and Y. Enzel, 2009: Bathymetry of Lake Lisan controls late Pleistocene and Holocene stream incision in response to base level fall. Geomorphology, 106, 352-362, https://doi.org/ 10.1016/j.geomorph.2008.11.014.
Dayan, U., and R. Abramski, 1983: Heavy rain in the Middle East related to unusual jet stream properties. Bull. Amer. Meteor. Soc., 64, 1138-1140, https://doi.org/10.1175/1520-0477(1983) 064<1138:HRITME > 2.0.CO;2.

— the Dead Sea: A review. Geol. Soc. Amer. Spec. Pap., 401, 5362, https://doi.org/10.1130/2006.2401(04).

Dee, D. P., and Coauthors, 2011: The ERA-Interim reanalysis: Configuration and performance of the data assimilation system. Quart. J. Roy. Meteor. Soc., 137, 553-597, https://doi.org/10.1002/qj.828.

Deng, L., M. F. McCabe, G. Stenchikov, J. P. Evans, and P. A. Kucera, 2015: Simulation of flash-flood-producing storm events in Saudi Arabia using the Weather Research and Forecasting Model. J. Hydrometeor., 16, 615-630, https:// doi.org/10.1175/JHM-D-14-0126.1.

Dente, E., N. G. Lensky, E. Morin, T. Grodek, N. A. Sheffer, and Y. Enzel, 2017: Geomorphic response of a low-gradient channel to modern, progressive base-level lowering: Nahal HaArava, the Dead Sea. J. Geophys. Res. Earth Surf., 122, 2468-2487, https://doi.org/10.1002/2016JF004081.

de Vries, A. J., E. Tyrlis, D. Edry, S. O. Krichak, B. Steil, and J. Lelieveld, 2013: Extreme precipitation events in the Middle East: Dynamics of the Active Red Sea Trough. J. Geophys. Res. Atmos., 118, 7087-7108, https://doi.org/ 10.1002/jgrd.50569.

- S. B. Feldstein, E. Tyrlis, M. Riemer, M. Baumgart, M. Fnais, M. Sprenger, and J. Lelieveld, 2016: Dynamics of tropicalextratropical interactions and extreme precipitation events in Saudi Arabia in autumn, winter and spring. Quart. J. Roy. Meteor. Soc., 142, 1862-1880, https://doi.org/10.1002/qj.2781.

Doswell, C. A., H. E. Brooks, and R. A. Maddox, 1996: Flash flood forecasting: An ingredients-based methodology. Wea. Forecasting, 11, 560-581, https://doi.org/10.1175/1520-0434(1996) 011<0560:FFFAIB > 2.0.CO;2.

Ely, L. L., Y. Enzel, and D. R. Cayan, 1994: Anomalous North Pacific atmospheric circulation and large winter floods in the southwestern United States. J. Climate, 7, 977-987, https://doi.org/ 10.1175/1520-0442(1994)007<0977:ANPACA > 2.0.CO;2.

Enzel, Y., D. R. Cayan, R. Y. Anderson, and S. G. Wells, 1989: Atmospheric circulation during Holocene lake stands in the Mojave Desert: Evidence of regional climate change. Nature, 341, 44-47, https://doi.org/10.1038/341044a0.

W. J. Brown, R. Y. Anderson, L. D. McFadden, and S. G. Wells, 1992: Short-duration Holocene lakes in the Mojave River drainage basin, southern California. Quat. Res., 38, 6073, https://doi.org/10.1016/0033-5894(92)90030-M.

- R. Bookman, D. Sharon, H. Gvirtzman, U. Dayan, B. Ziv, and M. Stein, 2003: Late Holocene climates of the Near East deduced from Dead Sea level variations and modern regional winter rainfall. Quat. Res., 60, 263-273, https://doi.org/10.1016/ j.yqres.2003.07.011.

_ , R. Amit, U. Dayan, O. Crouvi, R. Kahana, B. Ziv, and D. Sharon, 2008: The climatic and physiographic controls of the eastern Mediterranean over the late Pleistocene climates in the southern Levant and its neighboring deserts. Global Planet. Change, 60, 165-192, https://doi.org/10.1016/j.gloplacha.2007.02.003.

- and Coauthors, 2012: Late Quaternary weathering, erosion, and deposition in Nahal Yael, Israel: An "impact of climatic change on an arid watershed"? Bull. Geol. Soc. Amer., 124, 705-722, https://doi.org/10.1130/B30538.1.

, Y. Kushnir, and J. Quade, 2015: The middle Holocene climatic records from Arabia: Reassessing lacustrine environments, shift of ITCZ in Arabian Sea, and impacts of the southwest Indian 
and African monsoons. Global Planet. Change, 129, 69-91, https://doi.org/10.1016/j.gloplacha.2015.03.004.

Farhan, Y., and A. Anbar, 2014: Fragile landscape: Impact and consequences of May 2014 flash-flood disaster in the Aqaba area, southern Jordan. Res. J. Environ. Earth Sci., 6, 451-465.

Fekete, B. M., C. J. Vorosmarty, J. O. Roads, and C. J. Willmott, 2004: Uncertainties in precipitation and their impacts on runoff estimates. J. Climate, 17, 294-304, https://doi.org/ 10.1175/1520-0442(2004)017<0294:UIPATI>2.0.CO;2.

Gimeno, L., and Coauthors, 2012: Oceanic and terrestrial sources of continental precipitation. Rev. Geophys., 50, RG4003, https://doi.org/10.1029/2012RG000389.

Ginat, H., and B. Shalmon, 2014: Last rain in the southern Negev and Arava in May 2014 (in Hebrew). Negev, Dead Sea Arava Stud., 6, 59-62.

Goldreich, Y., 1994: The spatial distribution of annual rainfall in Israel-A review. Theor. Appl. Climatol., 50, 45-59, https:// doi.org/10.1007/BF00864902.

— , 2012: The Climate of Israel: Observation, Research and Application. Springer, $270 \mathrm{pp}$.

— H. Mozes, and D. Rosenfeld, 2004: Radar analysis of cloud systems and their rainfall yield in Israel. Isr. J. Earth Sci., 53, 63-76, https://doi.org/10.1560/G68K-30MN-D5V0-KUHU.

Greenbaum, N., A. P. Schick, and V. R. Baker, 2000: The palaeoflood record of a hyperarid catchment, Nahal Zin, Negev Desert, Israel. Earth Surf. Processes Landforms, 25, 951-971, https://doi.org/10.1002/1096-9837(200008)25: 9<951::AID-ESP110>3.0.CO;2-8.

—, Y. Enzel, and A. P. Schick, 2001a: Magnitude and frequency of paleofloods and historical floods in the Arava basin, Negev Desert, Israel. Isr. J. Earth Sci., 50, 159-186, https://doi.org/ 10.1092/N5VU-FU5F-QNWC-UDCK.

, U. Schwartz, A. P. Schick, and Y. Enzel, 2001b: Paleofloods and the estimation of long-term transmission losses and recharge to the lower Nahal Zin alluvial aquifer, Negev Desert, Israel. Ancient Floods, Modern Hazards, P. K. House et al., Eds., Water Science and Application Series, Vol. 5, Amer. Geophys. Union, 311-328, https://doi.org/10.1029/WS005p0311.

—_ A. Ben-Zvi, I. Haviv, and Y. Enzel, 2006a: The hydrology and paleohydrology of the Dead Sea tributaries. Spec. Pap. Geol. Soc. Amer., 401, 63-93, https://doi.org/10.1130/ 2006.2401(05).

—, N. Porat, E. Rhodes, and Y. Enzel, 2006b: Large floods during late Oxygen Isotope Stage 3, southern Negev desert, Israel. Quat. Sci. Rev., 25, 704-719, https://doi.org/10.1016/ j.quascirev.2005.07.008.

Grodek, T., Y. Jacoby, E. Morin, and O. Katz, 2012: Effectiveness of exceptional rainstorms on a small Mediterranean basin. Geomorphology, 159-160, 156-168, https://doi.org/ 10.1016/j.geomorph.2012.03.016.

Hirschboeck, K. K., 1987: Hydroclimatically-defined mixed distributions in partial duration flood series. Hydrologic Frequency Modeling: Proceedings of the International Symposium on Flood Frequency and Risk Analyses, V. P. Singh, Ed., Springer, 199-212, https://doi.org/10.1007/978-94-009-3953-0_13.

— , L. L. Ely, and R. A. Maddox, 2000: Hydroclimatology of meteorologic floods. Inland Flood Hazards: Human, Riparian and Aquatic Communities, E. Wohl, Ed., Cambridge University Press, 39-72.

IMS, 2016: Israel Meteorological Service database (in Hebrew). Accessed 20 July 2016, https://ims.data.gov.il.

Issar, A., A. Bein, and A. Michaeli, 1972: On the ancient water of the upper Nubain sandstone aquifer in central Sinai and southern Israel. J. Hydrol., 17, 353-374, https://doi.org/ 10.1016/0022-1694(72)90092-3.

Kahana, R., B. Ziv, Y. Enzel, and U. Dayan, 2002: Synoptic climatology of major floods in the Negev Desert, Israel. Int. J. Climatol., 22, 867-882, https://doi.org/10.1002/joc.766.

Kalma, J. D., and S. W. Franks, 2003: Rainfall in arid and semi-arid regions. Understanding Water in a Dry Environment, I. Simmers, Ed., Taylor \& Francis, 15-64.

Kirby, M. E., S. R. H. Zimmerman, W. P. Patterson, and J. J. Rivera, 2012: A 9170-year record of decadal-to-multicentennial scale pluvial episodes from the coastal Southwest United States: A role for atmospheric rivers? Quat. Sci. Rev., 46, 57-65, https://doi.org/10.1016/j.quascirev.2012.05.008.

Knapp, K. R., 2008: Scientific data stewardship of international satellite cloud climatology project B1 global geostationary observations. J. Appl. Remote Sens., 2, 023548, https://doi.org/ 10.1117/1.3043461.

Knippertz, P., 2005: Tropical-extratropical interactions associated with an Atlantic tropical plume and subtropical jet streak. Mon. Wea. Rev., 133, 2759-2776, https://doi.org/10.1175/MWR2999.1. , 2007: Tropical-extratropical interactions related to upperlevel troughs at low latitudes. Dyn. Atmos. Oceans, 43, 36-62, https://doi.org/10.1016/j.dynatmoce.2006.06.003.

_ , and J. E. Martin, 2007: A Pacific moisture conveyor belt and its relationship to a significant precipitation event in the semiarid southwestern United States. Wea. Forecasting, 22, 125-144, https://doi.org/10.1175/WAF963.1.

— moisture exports to the Northern Hemispheric extratropics. J. Climate, 23, 987-1003, https://doi.org/10.1175/2009JCLI3333.1.

Konrad, C. P., and M. D. Dettinger, 2017: Flood runoff in relation to water vapor transport by atmospheric rivers over the western United States, 1949-2015. Geophys. Res. Lett., 44, 11 456-11 462, https://doi.org/10.1002/2017GL075399.

Krajewski, W. F., and J. A. Smith, 2002: Radar hydrology: Rainfall estimation. Adv. Water Resour., 25, 1387-1394, https://doi.org/ 10.1016/S0309-1708(02)00062-3.

Krichak, S. O., and P. Alpert, 1998: Role of large scale moist dynamics in November 1-5, 1994, hazardous Mediterranean weather. J. Geophys. Res., 103, 19453-19468, https://doi.org/ 10.1029/98JD01710.

,-- , and T. N. Krishnamurti, 1997: Interaction of topography and tropospheric flow-A possible generator for the Red Sea Trough? Meteor. Atmos. Phys., 63, 149-158, https://doi.org/ 10.1007/BF01027381.

_- M. Tsidulko, and P. Alpert, 2000: November 2, 1994, severe storms in the southeastern Mediterranean. Atmos. Res., 53, 45-62, https://doi.org/10.1016/S0169-8095(99)00045-9.

Kushnir, Y., U. Dayan, B. Ziv, E. Morin, and Y. Enzel, 2017: Climate of the Levant: Phenomena and mechanisms. Quaternary of the Levant: Environments, Climate Change, and Humans, Y. Enzel and B.-Y. Ofer, Eds., Cambridge University Press, 31-44.

Lange, J., and C. Leibundgut, 2003: Surface runoff and sediment dynamics in arid and semi-arid regions. Understanding Water in a Dry Environment, I. Simmers, Ed., Taylor \& Francis, 115-150.

Ludwig, P., E. J. Schaffernicht, Y. Shao, and J. G. Pinto, 2016: Regional atmospheric circulation over Europe during the Last Glacial Maximum and its links to precipitation. J. Geophys. Res. Atmos., 121, 2130-2145, https://doi.org/10.1002/2015JD024444.

Luo, D., Y. Yao, A. Dai, and S. B. Feldstein, 2015: The positive North Atlantic oscillation with downstream blocking and Middle East snowstorms: The large-scale environment. J. Climate, 28, 6398-6418, https://doi.org/10.1175/JCLI-D-15-0184.1. 
Mabbutt, J. A., 1977: Desert Landforms. MIT Press, 340 pp.

Maley, J., 2000: Last Glacial Maximum lacustrine and fluviatile formations in the Tibesti and other Saharan mountains, and large-scale climatic teleconnections linked to the activity of the subtropical jet stream. Global Planet. Change, 26, 121-136, https://doi.org/10.1016/S0921-8181(00)00039-4.

Marra, F., and E. Morin, 2015: Use of radar QPE for the derivation of intensity-duration-frequency curves in a range of climatic regimes. J. Hydrol., 531, 427-440, https://doi.org/10.1016/ j.jhydrol.2015.08.064.

— , and — 2018: Autocorrelation structure of convective rainfall in semiarid-arid climate derived from high-resolution X-band radar estimates. Atmos. Res., 200, 126-138, https:// doi.org/10.1016/j.atmosres.2017.09.020.

Matmon, A., S. Elfassi, A. Hidy, Y. Geller, N. Porat, and ASTER Team, 2016: Controls on aggradation and incision in the NE Negev, Israel, since the middle Pleistocene. Geomorphology, 261, 132-146, https://doi.org/10.1016/j.geomorph.2016.02.020.

McGuirk, J. P., A. H. Thompson, and N. R. Smith, 1987: Moisture bursts over the tropical Pacific Ocean. Mon. Wea. Rev., 115, 787-798, https://doi.org/10.1175/1520-0493(1987)115<0787: MBOTTP $>2.0 . \mathrm{CO} ; 2$.

Meirovich, L., A. Ben-Zvi, I. Shentsis, and E. Yanovich, 1998: Frequency and magnitude of runoff events in the arid Negev of Israel. J. Hydrol., 207, 204-219, https://doi.org/10.1016/ S0022-1694(98)00135-8.

Merz, N., C. C. Raible, and T. Woollings, 2015: North Atlantic eddydriven jet in interglacial and glacial winter climates. J. Climate, 28, 3977-3997, https://doi.org/10.1175/JCLI-D-14-00525.1.

Morin, E., and M. Gabella, 2007: Radar-based quantitative precipitation estimation over Mediterranean and dry climate regimes. J. Geophys. Res., 112, D20108, https://doi.org/10.1029/ 2006JD008206.

—, and H. Yakir, 2014: Hydrological impact and potential flooding of convective rain cells in a semi-arid environment. Hydrol. Sci. J., 59, 1353-1362, https://doi.org/ 10.1080/02626667.2013.841315.

_ - Y. Jacoby, S. Navon, and E. Bet-Halachmi, 2009: Towards flash-flood prediction in the dry Dead Sea region utilizing radar rainfall information. Adv. Water Resour., 32, 1066-1076, https://doi.org/10.1016/j.advwatres.2008.11.011.

Nehorai, R., I. M. Lensky, L. Hochman, I. Gertman, S. Brenner, A. Muskin, and N. G. Lensky, 2013: Satellite observations of turbidity in the Dead Sea. J. Geophys. Res. Oceans, 118, 31463160, https://doi.org/10.1002/jgrc.20204.

Neugebauer, I., and Coauthors, 2014: Lithology of the long sediment record recovered by the ICDP Dead Sea Deep Drilling Project (DSDDP). Quat. Sci. Rev., 102, 149-165, https:// doi.org/10.1016/j.quascirev.2014.08.013.

O'Connor, J. E., and J. E. Costa, 2004: Spatial distribution of the largest rainfall-runoff floods from basins between 2.6 and $26,000 \mathrm{~km}^{2}$ in the United States and Puerto Rico. Water Resour. Res., 40, W01107, https://doi.org/10.1029/2003WR002247.

Panziera, L., C. N. James, and U. Germann, 2015: Mesoscale organization and structure of orographic precipitation producing flash floods in the Lago Maggiore region. Quart. J. Roy. Meteor. Soc., 141, 224-248, https://doi.org/10.1002/qj.2351.

Peleg, N., and E. Morin, 2012: Convective rain cells: Radar-derived spatiotemporal characteristics and synoptic patterns over the eastern Mediterranean. J. Geophys. Res., 117, D15116, https:// doi.org/10.1029/2011JD017353.

Ralph, F. M., and Coauthors, 2017: Atmospheric rivers emerge as a global science and applications focus. Bull.
Amer. Meteor. Soc., 98, 1969-1973, https://doi.org/10.1175/ BAMS-D-16-0262.1.

Rubin, S., B. Ziv, and N. Paldor, 2007: Tropical plumes over eastern North Africa as a source of rain in the Middle East. Mon. Wea. Rev., 135, 4135-4148, https://doi.org/10.1175/ 2007MWR1919.1.

Saaroni, H., and B. Ziv, 2000: Summer rain episodes in a Mediterranean climate, the case of Israel: Climatological-dynamical analysis. Int. J. Climatol., 20, 191-209, https://doi.org/10.1002/ (SICI)1097-0088(200002)20:2<191::AID-JOC464>3.0.CO;2-E.

Salomon, R., E. Morin, Y. Enzel, and I. Haviv, 2016: Evolution of gravel-bed channels in response to flash floods in dry environments. Geophysical Research Abstracts, Vol. 18, Abstract EGU2016-9025-1, http://meetingorganizer.copernicus.org/ EGU2016/EGU2016-9025-1.pdf.

Schick, A. P., 1988: Hydrologic aspects of floods in extreme arid environments. Flood Geomorphology, V. R. Baker, R. C. Kochel, and P. C. Patton, Eds., John Wiley and Sons, 189-203.

Sharon, D., 1979: Correlation analysis of the Jordan valley rainfall field. Mon. Wea. Rev., 107, 1042-1047, https://doi.org/10.1175/ 1520-0493(1979)107<1042:CAOTJV>2.0.CO;2.

— , and H. Kutiel, 1986: The distribution of rainfall intensity in Israel, its regional and seasonal variations and its climatological evaluation. J. Climatol., 6, 277-291, https://doi.org/10.1002/ joc.3370060304.

Shentsis, I., J. B. Laronne, and P. Alpert, 2012: Red Sea trough flood events in the Negev, Israel (1964-2007). Hydrol. Sci. J., 57, 42-51, https://doi.org/10.1080/02626667.2011.636922.

Skinner, C. B., and C. J. Poulsen, 2016: The role of fall season tropical plumes in enhancing Saharan rainfall during the African humid period. Geophys. Res. Lett., 43, 349-358, https:// doi.org/10.1002/2015GL066318.

Smith, J. A., M. L. Baeck, A. A. Ntelekos, G. Villarini, and M. Steiner, 2011a: Extreme rainfall and flooding from orographic thunderstorms in the central Appalachians. Water Resour. Res., 47, W04514, https://doi.org/10.1029/2010WR010190.

, G. Villarini, and M. L. Baeck, 2011b: Mixture distributions and the hydroclimatology of extreme rainfall and flooding in the eastern United States. J. Hydrometeor., 12, 294-309, https://doi.org/10.1175/2010JHM1242.1.

Sonntag, C., G. Thoma, K. O. Muennich, T. Dincer, and E. Klitzsch, 1980: Environmental isotopes in North African groundwaters; and the Dahna sand-dune study, Saudi Arabia. AridZone Hydrology: Investigations with Isotope Techniques, IAEA, 77-84.

Stein, A. F., R. R. Draxler, G. D. Rolph, B. J. B. Stunder, M. D. Cohen, and F. Ngan, 2015: NOAA's HYSPLIT atmospheric transport and dispersion modeling system. Bull. Amer. Meteor. Soc., 96, 2059-2077, https://doi.org/10.1175/BAMS-D-14-00110.1.

Sui, C.-H., X. Li, and M.-J. Yang, 2007: On the definition of precipitation efficiency. J. Atmos. Sci., 64, 4506-4513, https:// doi.org/10.1175/2007JAS2332.1.

Tarolli, P., M. Borga, E. Morin, and G. Delrieu, 2012: Analysis of flash flood regimes in the north-western and south-eastern Mediterranean regions. Nat. Hazards Earth Syst. Sci., 12, 1255-1265, https://doi.org/10.5194/nhess-12-1255-2012.

Torfstein, A., S. L. Goldstein, Y. Kushnir, Y. Enzel, G. Haug, and M. Stein, 2015: Dead Sea drawdown and monsoonal impacts in the Levant during the last interglacial. Earth Planet. Sci. Lett., 412, 235-244, https://doi.org/10.1016/j.epsl.2014.12.013.

Tsvieli, Y., and A. Zangvil, 2005: Synoptic climatological analysis of "wet" and "dry" Red Sea troughs over Israel. Int. J. Climatol., 25, 1997-2015, https://doi.org/10.1002/joc.1232. 
Tubi, A., and U. Dayan, 2014: Tropical plumes over the Middle East: Climatology and synoptic conditions. Atmos. Res., 145146, 168-181, https://doi.org/10.1016/j.atmosres.2014.03.028.

Vaks, A., and Coauthors, 2006: Paleoclimate and location of the border between Mediterranean climate region and the Saharo-Arabian Desert as revealed by speleothems from the northern Negev Desert, Israel. Earth Planet. Sci. Lett., 249, 384-399, https://doi.org/10.1016/j.epsl.2006.07.009.

Vengosh, A., S. Hening, J. Ganor, B. Mayer, C. E. Weyhenmeyer, T. D. Bullen, and A. Paytan, 2007: New isotopic evidence for the origin of groundwater from the Nubian Sandstone Aquifer in the Negev, Israel. Appl. Geochem., 22, 1052-1073, https:// doi.org/10.1016/j.apgeochem.2007.01.005.

Waldmann, N., A. Torfstein, and M. Stein, 2010: Northward intrusions of low- and mid-latitude storms across the SaharoArabian belt during past interglacials. Geology, 38, 567-570, https://doi.org/10.1130/G30654.1.

Wolman, M. G., and J. P. Miller, 1960: Magnitude and frequency of forces in geomorphic processes. J. Geol., 68, 54-74, https:// doi.org/10.1086/626637.
-_, and R. Gerson, 1978: Relative scales of time and effectiveness of climate in watershed geomorphology. Earth Surf. Processes, 3, 189-208, https://doi.org/10.1002/esp.3290030207.

Zangvil, A., and P. Druian, 1990: Upper air trough axis orientation and the spatial distribution of rainfall over Israel. Int. J. Climatol., 10, 57-62, https://doi.org/10.1002/joc.3370100107.

Ziv, B., 2001: A subtropical rainstorm associated with a tropical plume over Africa and the Middle-East. Theor. Appl. Climatol., 69, 91-102, https://doi.org/10.1007/s007040170037.

—, U. Dayan, and D. Sharon, 2005: A mid-winter, tropical extreme flood-producing storm in southern Israel: Synoptic scale analysis. Meteor. Atmos. Phys., 88, 53-63, https://doi.org/ 10.1007/s00703-003-0054-7.

- - — , Y. Kushnir, C. Roth, and Y. Enzel, 2006: Regional and global atmospheric patterns governing rainfall in the southern Levant. Int. J. Climatol., 26, 55-73, https://doi.org/10.1002/joc.1238.

_ - T. Harpaz, H. Saaroni, and R. Blender, 2015: A new methodology for identifying daughter cyclogenesis: application for the Mediterranean basin. Int. J. Climatol., 35, 3847-3861, https://doi.org/10.1002/joc.4250. 